\title{
Upper-tropospheric $\mathrm{CO}$ and $\mathrm{O}_{3}$ budget during the Asian summer monsoon
}

\author{
Brice Barret, Bastien Sauvage, Yasmine Bennouna, and Eric Le Flochmoen \\ Laboratoire d'Aérologie, Université de Toulouse, CNRS, UPS, Toulouse, France \\ Correspondence to: Brice Barret (barp@aero.obs-mip.fr)
}

Received: 13 December 2015 - Published in Atmos. Chem. Phys. Discuss.: 22 January 2016

Revised: 10 June 2016 - Accepted: 20 June 2016 - Published: 25 July 2016

\begin{abstract}
During the Asian summer monsoon, the circulation in the upper troposphere/lower stratosphere (UTLS) is dominated by the Asian monsoon anticyclone (AMA). Pollutants convectively uplifted to the upper troposphere are trapped within this anticyclonic circulation that extends from the Pacific Ocean to the Eastern Mediterranean basin. Among the uplifted pollutants are ozone $\left(\mathrm{O}_{3}\right)$ and its precursors, such as carbon monoxide (CO) and nitrogen oxides $\left(\mathrm{NO}_{x}\right)$. Many studies based on global modeling and satellite data have documented the source regions and transport pathways of primary pollutants $(\mathrm{CO}, \mathrm{HCN})$ into the AMA. Here, we aim to quantify the $\mathrm{O}_{3}$ budget by taking into consideration anthropogenic and natural sources. We first use $\mathrm{CO}$ and $\mathrm{O}_{3}$ data from the MetOp-A/IASI sensor to document their tropospheric distributions over Asia, taking advantage of the useful information they provide on the vertical dimension. These satellite data are used together with MOZAIC tropospheric profiles recorded in India to validate the distributions simulated by the global GEOS-Chem chemistry transport model. Over the Asian region, UTLS monthly $\mathrm{CO}$ and $\mathrm{O}_{3}$ distributions from IASI and GEOS-Chem display the same large-scale features. UTLS CO columns from GEOS-Chem are in agreement with IASI, with a low bias of $11 \pm 9 \%$ and a correlation coefficient of 0.70 . For $\mathrm{O}_{3}$, the model underestimates IASI UTLS columns over Asia by $14 \pm 26 \%$ but the correlation between both is high (0.94). GEOS-Chem is further used to quantify the $\mathrm{CO}$ and $\mathrm{O}_{3}$ budget through sensitivity simulations. For $\mathrm{CO}$, these simulations confirm that South Asian anthropogenic emissions have a more important impact on enhanced concentrations within the AMA ( $~ 25$ ppbv) than East Asian emissions $(\sim 10 \mathrm{ppbv})$. The correlation between enhanced emissions over the Indo-Gangetic Plain and monsoon deep convec-
\end{abstract}

tion is responsible for this larger impact. Consistently, South Asian anthropogenic $\mathrm{NO}_{x}$ emissions also play a larger role in producing $\mathrm{O}_{3}$ within the AMA ( $\sim 8$ ppbv) than East Asian emissions $(\sim 5 \mathrm{ppbv})$, but Asian lightning-produced $\mathrm{NO}_{x}$ is responsible for the largest $\mathrm{O}_{3}$ production (10-14 ppbv). Stratosphere-to-troposphere exchanges are also important in transporting $\mathrm{O}_{3}$ in the upper part of the AMA.

\section{Introduction}

Tropospheric $\mathrm{O}_{3}$ plays an important role in determining the radiative budget of the atmosphere and has a non-negligible impact on climate change. In particular, according to Shindell et al. (2006), the fast economic growth of developing countries has led to an increase in tropospheric $\mathrm{O}_{3}$, which may be responsible for the fast warming observed in the tropics over the last half of the 20th century. Based on GCM simulations, Chen et al. (2007) have also shown that the changes in tropospheric $\mathrm{O}_{3}$ predicted for the 21 st century are likely to increase the atmospheric radiative forcing throughout the troposphere but more specifically in the tropical upper troposphere/lower stratosphere (UTLS). The understanding of the $\mathrm{O}_{3}$ budget in this atmospheric region is therefore an important issue to better address future tropospheric $\mathrm{O}_{3}$ radiative forcing.

During boreal summer, the northern-hemispheric tropical tropospheric circulation is dominated by the Asian summer monsoon (ASM), which is characterized by a strong southwesterly flow in the lower troposphere converging over South and Southeast Asia and results in deep convective activity over this region. During the ASM, an upper-level anticyclonic circulation, the Asian monsoon an- 
ticyclone (AMA), builds up in response to deep convection (Hoskins and Rodwell, 1995; Garny and Randel, 2013). Based on CO UTLS data provided by the Aura/MLS (Microwave Limb Sensor) sensor, Li et al. (2005), Park et al. (2007) and Barret et al. (2008) have shown that during the ASM polluted air masses were convectively uplifted to the UTLS and trapped within AMA circulation. Based on ACEFTS data, Park et al. (2008) have also pointed out that, similarly to $\mathrm{CO}, \mathrm{HCN}$ is trapped within the AMA. Randel et al. (2010) have further highlighted that HCN from the AMA is uplifted into the stratosphere within the ascending branch of the Brewer-Dobson circulation. Data from the AIRS sensor were also used to show that the uplift of $\mathrm{O}_{3}$-poor and $\mathrm{H}_{2} \mathrm{O}$ rich air masses from the planetary boundary layer (PBL) is responsible for low $\mathrm{O}_{3}$ within the AMA (Randel and Park, 2006). The AMA therefore appears to be an isolated atmospheric region with its physical properties and its composition likely little impacted by emissions and processes from remote regions.

Recent studies based on transport modeling have tried to determine the origin of the air masses convectively uplifted and trapped within the AMA. For instance, based on Lagrangian dispersion modeling forced with a set of reanalyzes from different systems, Bergman et al. (2013) argue that PBL air masses impacting the AMA are uplifted within a conduit centered over Northeast India, Nepal and southern Tibet. Using high-resolution WRF meteorological forcing for back trajectory simulations, Heath and Fuelberg (2014) have demonstrated that most of the air parcels convectively uplifted from the PBL and ending up in the AMA at $100 \mathrm{hPa}$ originate in the Tibetan Plateau or the Himalayan southern slopes. Nevertheless, these studies based on Lagrangian modeling are not able to document the origin of pollutants in the AMA, which depends on the distribution of their sources. It is noteworthy that convection from the Tibetan Plateau, highlighted as predominant to fill the AMA by the cited studies (Bergman et al., 2013; Heath and Fuelberg, 2014), probably plays a minor role in the transport of pollutants due to its very low pollution sources. From simulations with a global chemistry transport model (CTM), Park et al. (2009) have highlighted that most of the CO trapped within the AMA at $100 \mathrm{hPa}$ comes from India and Southeast Asia and to a lesser extent from eastern China. A more recent study based on similar simulations with the WRF-Chem limited area model comes to similar conclusions (Yan and Bian, 2015). According to Park et al. (2009), almost no CO originates from the Tibetan Plateau. Also based on CTM simulations, Li et al. (2005) point to Northeast India and southwestern China as the origin of upper-tropospheric CO trapped within the AMA.

Based on CTM sensitivity simulations, Kunhikrishnan et al. (2004) have quantified the impact of surface $\mathrm{NO}_{x}$ from India and the neighboring regions on the $\mathrm{O}_{3}$ budget over India. Their results show that $\mathrm{O}_{3}$ in the Indian middle-upper troposphere $(500-150 \mathrm{hPa})$ during the monsoon is mostly produced by regional (Indian) $\mathrm{NO}_{x}$ emissions uplifted by convection. In particular, they point to a larger impact of $\mathrm{NO}_{x}$ local surface sources relative to the lightning-produced $\mathrm{NO}_{x}\left(\mathrm{LiNO}_{x}\right)$ source on the $\mathrm{NO}_{x}$ concentration in the 500 $150 \mathrm{hPa}$ layer during the monsoon. Based on in situ data recorded at the Himalayan NCO-P observatory, Cristofanelli et al. (2010) have shown that high-altitude (5049 m a.s.l.) $\mathrm{O}_{3}$ has a marked seasonal cycle with a maximum of around $60 \mathrm{ppbv}$ during the pre-monsoon season and a minimum of 40 ppbv during the monsoon season. They show that this annual cycle is largely related to stratosphere-to-troposphere exchanges (STE) which occur about $20 \%$ of the time all year round except during the monsoon season. During the October-May period, the subtropical westerly jet (SWJ) is located between 25 and $30^{\circ} \mathrm{N}$, promoting deep STE over the southern Himalayas. During the ASM, the SWJ is pushed northwards of the Tibetan Plateau by the AMA, and STE to the central Himalayas are blocked.

Previous studies (Kunhikrishnan et al., 2004, 2006) have therefore dealt with the $\mathrm{O}_{3}$ budget in the Indian troposphere, but the $\mathrm{O}_{3}$ budget of the AMA has not yet been addressed in detail. In particular, it is not yet known to what extent the different $\mathrm{NO}_{x}$ sources are responsible for an increase in the $\mathrm{O}_{3}$ concentrations within this upper-level large-scale circulation characterized by rather low $\mathrm{O}_{3}$ concentrations. Furthermore, satellite data from the IASI sensor have been available since 2007 but they have not yet been used to document the ASM. These data are complementary to MLS data that have been extensively used in the region (Park et al., 2009; Barret et al., 2008) because, although they have a coarse vertical resolution, they cover both the troposphere and the UTLS. Here, we aim to characterize the impact of STE and of $\mathrm{NO}_{x}$ emissions from the different sources and regions on the $\mathrm{O}_{3}$ budget in the South Asian UTLS during the monsoon season. We also use $\mathrm{CO}$ as a tracer of surface pollution that brings direct information about the origin of the air masses. We focus on the AMA in order to determine the role of its dynamical structure and isolation upon the regional upper-tropospheric $\mathrm{O}_{3}$ budget. The second section of this paper is dedicated to the description of the observations (IASI and MOZAIC) and of the chemistry transport model GEOS-Chem (GC) that are used in our study. In Sect. 3, we make use of IASI and MOZAIC $\mathrm{O}_{3}$ and $\mathrm{CO}$ data to validate their distributions simulated by the GC model over Asia. In Sect. 4, we discuss the dynamical and chemical characteristics of the AMA and the role of convection in controlling the distributions of $\mathrm{CO}$ and $\mathrm{O}_{3}$ during the ASM. Finally, in Sect. 5 the model is used to determine the impact of regional pollution uplift, $\mathrm{LiNO}_{x}$ and STE upon the $\mathrm{CO}$ and $\mathrm{O}_{3}$ concentrations within this upper-level AMA. Section 6 provides a summary and conclusions. 


\section{Observations and model}

\subsection{IASI $\mathrm{O}_{3}$ and $\mathrm{CO}$ observations}

The IASI instrument has been developed to fly on board the MetOp polar-orbiting platforms. The first two platforms, MetOp-A and B, were successfully launched in 2006 and 2012 respectively. IASI is a nadir-viewing Fourier transform spectrometer observing the Earth-atmosphere thermal infrared radiation in the $645-2760 \mathrm{~cm}^{-1}$ wavenumber region (see, e.g., Clerbaux et al., 2009) with a resolution of $0.5 \mathrm{~cm}^{-1}$ after apodization. IASI provides global Earth coverage twice a day, with an overpass time at $\sim 09: 30$ and $\sim 21: 30$ local time and a pixel size on the ground of $12 \mathrm{~km}$ at nadir.

IASI's primary objective is the delivery of accurate meteorological products to help to improve operational weather predictions. The IASI sensor can also monitor the tropospheric content of atmospheric trace gases such as $\mathrm{O}_{3}$ (Eremenko et al., 2008; Barret et al., 2011) and CO (George et al., 2009; De Wachter et al., 2012). In the present study, we use data provided by the Software for a Fast Retrieval of IASI Data (SOFRID) presented in Barret et al. (2011) for $\mathrm{O}_{3}$ and in De Wachter et al. (2012) for CO. In their study, Barret et al. (2011) showed that IASI enabled the independent retrieval of $\mathrm{O}_{3}$ in the lower-middle troposphere (surface-225 hPa) and in the UTLS (225-70 hPa) in the tropics. Moreover, comparisons of SOFRID $\mathrm{O}_{3}$ data with data from $\mathrm{O}_{3}$ sondes have shown that the agreement is especially good for the UTLS column $(225-70 \mathrm{hPa})$ with correlation coefficients of 0.8 (resp. 0.95) and biases of $17.5 \pm 20 \%$ (resp. $10 \pm 10 \%$ ) in Dufour et al. (2012) (resp. Barret et al., 2011). The ability of SOFRID to capture $\mathrm{O}_{3}$ daily variations in the tropical upper troposphere has also been demonstrated and validated against MOZAIC cruise data in Tocquer et al. (2015). The SOFRID CO data have been validated against MOZAIC data in De Wachter et al. (2012). SOFRID data are able to capture the seasonal variability of CO at midlatitudes (Frankfurt) as well as at tropical latitudes (Windhoek) in the lower (upper) troposphere with correlation coefficients of $0.85(0.70)$. At Windhoek, in the lower (upper) troposphere SOFRID CO data are biased low with $13 \pm 20 \%(4 \pm 12 \%)$ compared to MOZAIC data.

\subsection{MOZAIC $\mathrm{O}_{3}$ and $\mathrm{CO}$ observations}

The MOZAIC program was set up to provide routine measurements of reactive gases on long-distance commercial aircraft (Marenco et al., 1998). In 1994, five airliners were equipped with $\mathrm{O}_{3}$ and relative humidity instruments, and a CO analyzer was successfully added in December 2001. MOZAIC aircraft operations have stopped at the end of 2014. However, since 2011, a new set of instruments has been flying on commercial in-service aircraft in the frame of the IAGOS (In-service Aircraft for a Global Observing System) Research Infrastructure. IAGOS builds on the scien- tific and technological experience gained within the two predecessors programs: MOZAIC and CARIBIC (http://www. caribic-atmospheric.com). The MOZAIC and IAGOS data follow the same calibration and quality control procedures and are freely accessible for scientific use at http://www. iagos.fr. The MOZAIC and IAGOS data are freely accessible for scientific use at http://www.iagos.org. These measurements are carried out with a 30 (4) s response time corresponding to a resolution of about 7 (1) $\mathrm{km}$ at cruise altitude and a vertical resolution of about 300 (30) m during ascents and descents, with a reported precision of \pm 5 (1) ppbv for CO (Nedelec et al., 2003) $\left(\mathrm{O}_{3}\right.$; Thouret et al., 1998). For the present study, we used MOZAIC profiles measured at take off and landing near Hyderabad $\left(17.2^{\circ} \mathrm{N}, 78.3^{\circ} \mathrm{E}\right)$ in central India from May to October 2009. CO data were available for each month but for $\mathrm{O}_{3}$ no data were produced in September and October following an instrument failure. For both gases, we could use from 10 to 16 profiles for each month with available data.

\subsection{GEOS-Chem configuration}

In order to compute the $\mathrm{CO}$ and $\mathrm{O}_{3}$ budgets in the Asian upper troposphere, we use the GC global chemistry transport model (Bey et al., 2001) version 9-01-01 with a setup similar to that described in Yamasoe et al. (2015). This model has been thoroughly evaluated over the tropics through comparisons with in situ and remote sensed measurements of $\mathrm{O}_{3}$, $\mathrm{CO}, \mathrm{NO}_{2}$ and $\mathrm{HNO}_{3}$ (e.g., Martin et al., 2002; Sauvage et al., 2007a; Yamasoe et al., 2015). GC is driven offline by the meteorological analyses from the Goddard Earth Observing System (GEOS-5) of the NASA Global Modeling and Assimilation Office (GMAO). Tropospheric chemistry includes both $\mathrm{O}_{3}-\mathrm{NO}_{x}$ hydrocarbons and aerosols chemistry. Stratospheric $\mathrm{O}_{3}$ chemistry is computed with the linearized Linoz stratospheric ozone scheme developed by McLinden et al. (2000). STE are diagnosed with tagged $\mathrm{O}_{3}$ simulations including a stratospheric $\mathrm{O}_{3}$ tracer. Convection is parameterized with the relaxed Arakawa-Schubert scheme (Moorthi and Suarez, 1992) in GEOS-5. Turbulent mixing in the planetary boundary layer is described in $\mathrm{Wu}$ et al. (2007). The simulations are performed on a regular $2^{\circ} \times 2.5^{\circ}$ horizontal grid and on 47 hybrid sigma-pressure levels from the surface up to $0.01 \mathrm{hPa}$. Emissions from biomass burning (BB) come from the monthly Global Fire Emissions Database version 2 (GFED-v2) (van der Werf et al., 2010). The global anthropogenic emissions are taken from the EDGAR v.4.1 inventory, which provides annual global emissions of greenhouse gases and ozone precursors on a $1^{\circ} \times 1^{\circ}$ horizontal grid, but typically the anthropogenic emissions are overwritten by data from various regional inventories. For instance over Asia we use the detailed inventory from Streets et al. (2006). Regional emission inventories are also used over Europe (EMEP), Canada (CAC), Mexico (BRAVO) and North America (EPA/NEI99 with ICARTT modifica- 
tion). All anthropogenic inventories are scaled for the year 2005. Biogenic emissions are taken from MEGAN v2.1. Detailed information on these emission inventories can be found at http://acmg.seas.harvard.edu/geos/doc/archive/man. v9-01-01/index.html. $\mathrm{NO}_{x}$ emissions from lightning are computed according to cloud top height parameterization (Price and Rind, 1994), rescaled with LIS-OTD climatology (Sauvage et al., 2007a; Murray et al., 2012) and are estimated at almost $6 \mathrm{Tg}(\mathrm{N})$ year $^{-1}$ (Martin et al., 2007).

We have performed 11 simulations for the May to October (MJJASO) period of 2009 with a 6-month spin-up. The control run was performed with all the emission sources considered. In order to determine the relative importance of the different sources on the $\mathrm{CO}$ and $\mathrm{O}_{3}$ Asian UTLS budgets, we have performed sensitivity runs with emissions alternatively switched off. For $\mathrm{CO}$, the sensitivity simulations concern South $\left(0-40^{\circ} \mathrm{N}, 60-100^{\circ} \mathrm{E}\right)$, East $\left(15-40^{\circ} \mathrm{N}\right.$, $\left.100-125^{\circ} \mathrm{E}\right)$ and Southeast $\left.10^{\circ} \mathrm{S}-15^{\circ} \mathrm{N}, 100-150^{\circ} \mathrm{E}\right)$ Asian anthropogenic and African $\left(20^{\circ} \mathrm{S}-20^{\circ} \mathrm{N}, 20^{\circ} \mathrm{W}-50^{\circ} \mathrm{E}\right) \mathrm{BB}$ emissions. For $\mathrm{O}_{3}$, we considered the impact of $\mathrm{NO}_{x}$ surface emissions from the same sources as for $\mathrm{CO}$ and the impact of $\mathrm{LiNO}_{x}$ emissions from the two monsoon regions, South Asia $\left(0-40^{\circ} \mathrm{N}, 60-100^{\circ} \mathrm{E}\right)$ and Africa $\left(20^{\circ} \mathrm{S}-20^{\circ} \mathrm{N}, 20^{\circ} \mathrm{W}-\right.$ $\left.50^{\circ} \mathrm{E}\right)$. In order to investigate the stratospheric contribution on the AMA tropospheric ozone budget (Sect. 5.2), we use a tagged ozone tracer to follow the stratospheric ozone flux across the tropopause as used in Sauvage et al. (2007b) and described by Fiore et al. (2002). The tagged simulation submits ozone produced in different regions of the atmosphere to archived three-dimensional fields of production and loss frequencies, allowing tropospheric ozone to be deconstructed into components from stratosphere and troposphere. The results from the sensitivity simulations are described and analyzed in Sect. 5.1 for the CO budget and in Sect. 5.2 for the $\mathrm{O}_{3}$ budget.

\subsection{IASI and GEOS-Chem comparisons}

In order to validate the $\mathrm{CO}$ and $\mathrm{O}_{3}$ distributions simulated by the GC model, we use SOFRID $\mathrm{CO}$ and $\mathrm{O}_{3}$ retrievals to have a regional view of these distributions. The comparisons are made for monthly averaged profiles on the $2^{\circ} \times 2.5^{\circ} \mathrm{GC}$ grid. The GC profiles are first interpolated on the 43 vertical retrieval levels from SOFRID. IASI vertical profiles have a vertical resolution $(\sim 6-8 \mathrm{~km})$ that is much lower than those modeled by GC (100 $\mathrm{m}$ to $1 \mathrm{~km})$. In order to take these resolution differences into account and make a sound comparison, we have to convolve the GC vertical interpolated profiles with IASI averaging kernels (AvK) according to the classical smoothing equation (e.g., Barret et al., 2005; De Wachter et al., 2012; Liu et al., 2009):

$\hat{\boldsymbol{x}}_{\mathrm{GC}}=\boldsymbol{x}_{\mathrm{a}}+\mathbf{A} \cdot\left(\boldsymbol{x}_{\mathrm{GC}}-\boldsymbol{x}_{\mathrm{a}}\right)$, where $\boldsymbol{x}_{\mathrm{GC}}$ and $\hat{\boldsymbol{x}}_{\mathrm{GC}}$ are the original and the smoothed or convolved GC profiles. A is the SOFRID AvK matrix which describes the sensitivity of the retrieved to the true profile (see Rodgers, 2000, for a description of the AvK matrix) and $\boldsymbol{x}_{\mathrm{a}}$ is the a priori profile used for the retrieval (the description of the a priori profiles can be found in Barret et al. (2011) for $\mathrm{O}_{3}$ and De Wachter et al. (2012) for $\mathrm{CO}$ ).

\section{Modeled vs. observed $\mathrm{CO}$ and $\mathrm{O}_{3}$ distributions}

The comparisons of the tropospheric $\mathrm{CO} / \mathrm{O}_{3}$ Asian distributions simulated by GC and observed by IASI enable us to evaluate the model's capacity to reproduce the large-scale features of the distributions and the possible causes of discrepancies. Airborne MOZAIC profiles measured in central India will provide a more precise evaluation of the absolute values simulated locally by the model.

\subsection{CO in the Asian troposphere}

The monthly distributions of UTLS $(270-110 \mathrm{hPa}) \mathrm{CO}$ columns from IASI and GC are displayed in Fig. 1 for the region extending from Africa to Indonesia and from $10^{\circ} \mathrm{S}$ to $40^{\circ} \mathrm{N}$ for the May (pre-monsoon) to October (post-monsoon) period. The dominant features of these distributions are the maxima over Africa and Asia. The statistics of the CO UTLS columns comparison (for the domain displayed in Fig. 1 and the 6 months from May to October) are summarized in Table 1 . GC underestimates the columns by $11 \pm 9 \%$ relative to IASI with a correlation coefficient of 0.70 . The smoothing has little impact on the bias but reduces the relative standard deviations of the differences and enhances the correlations. The comparison between GC simulations forced with GEOS5 analyses and MLS at $215 \mathrm{hPa}$ for the tropical band of Liu et al. (2013) gives similar results with a $10 \mathrm{ppbv}$ bias and a correlation coefficient of 0.65 .

Over Africa the observed maximum shifts from western Africa in May to central and southern Africa in July and September following the BB season (Sauvage et al., 2005). We notice that the GC upper-tropospheric $\mathrm{CO}$ distributions over Africa display the same kind of discrepancies with IASI than those shown by Liu et al. $(2010,2013)$ with MLS. Indeed, their GC simulations have CO concentrations that are systematically too low at $215 \mathrm{hPa}$ over central Africa in July (Liu et al., 2013) and from August to October (Liu et al., 2010). Furthermore, Barret et al. (2010) have shown that five CTMs using GFEDv2 for BB emissions underestimate the upper-tropospheric $\mathrm{CO}$ concentrations during the monsoon over Africa between $10^{\circ} \mathrm{S}$ and $5^{\circ} \mathrm{N}$ by up to $50 \mathrm{ppbv}$ compared to MOZAIC in situ data. The use of the BB emission inventory from Liousse et al. (2010) leads to a correction of these biases and even to an overestimation of modeled upper-tropospheric $\mathrm{CO}$ over Africa. The bias documented here probably results from too low BB emissions over central 


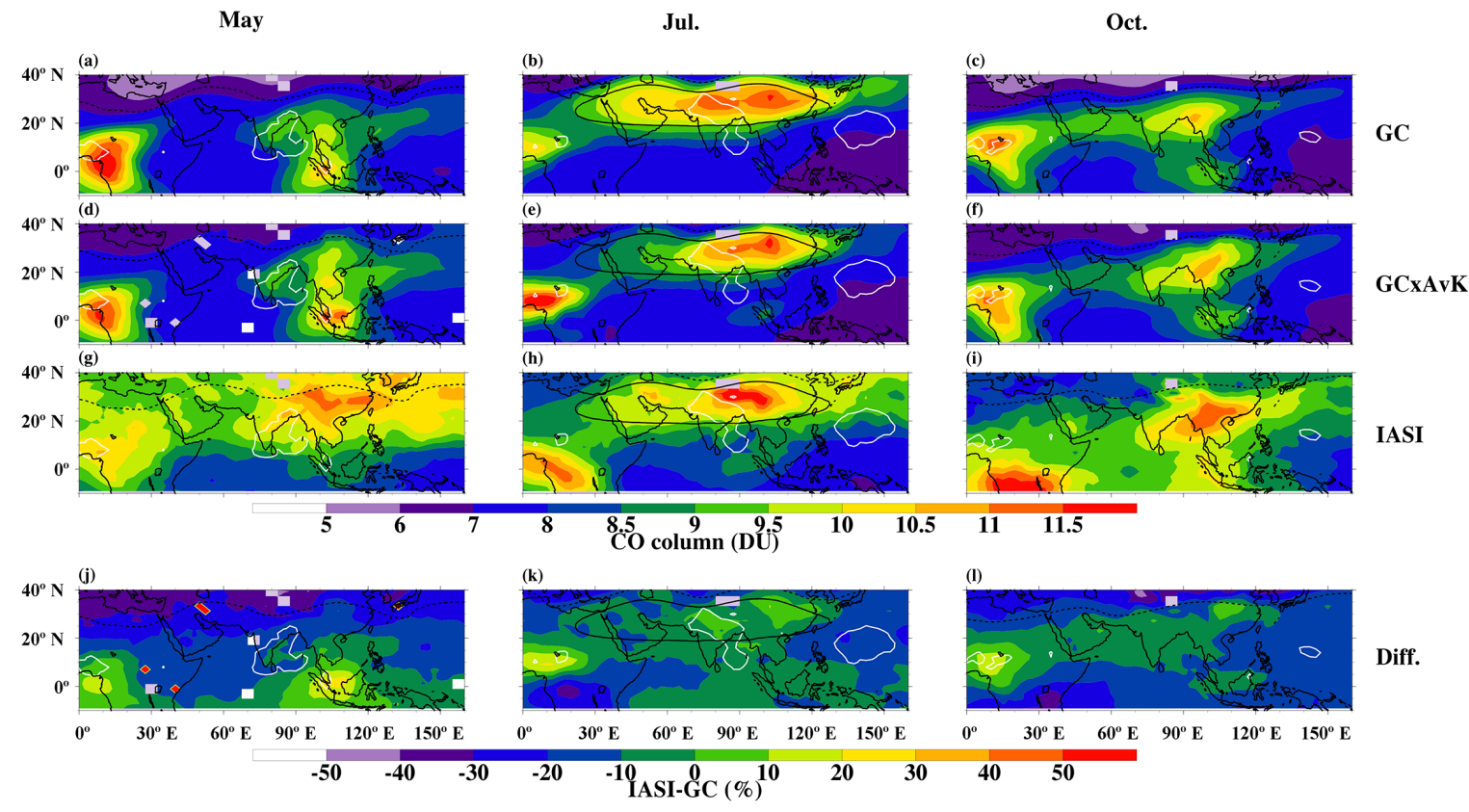

Figure 1. Distributions of UTLS (270-110 hPa) CO columns: (a, b, c) GEOS-Chem, (d, e, f) GEOS-Chem smoothed with IASI AvK, (g, h, i) IASI and $(\mathbf{j}, \mathbf{k}, \mathbf{l})$ relative differences between GC smoothed with IASI AvK and IASI. From left to right, panels correspond to monthly periods with (a, d, $\mathbf{g}, \mathbf{j})$ May, (b, e, h, k) July and (c, f, i, l) October. The white solid line represents the $2.5 \mathrm{~kg} \mathrm{~m}^{-2} \mathrm{~s}^{-1}$ convective upward mass flux from GEOS-5 averaged over $350-150 \mathrm{hPa}$. The black dashed line is the tropopause (2PVU) and the black solid line is the $12520 \mathrm{~m}$ $\mathrm{GH}$ representing the AMA boundary at $200 \mathrm{hPa}$.

and southern Africa from GFEDv2. Nevertheless, African $\mathrm{BB}$ emissions are not expected to impact the AMA composition and the observed biases will not impact our results.

Over Asia, which is the focus of our study, the highest CO columns are simulated by GC and detected by IASI over East Asia before the monsoon (May), over the continental convective region corresponding to northern India, Nepal and southern Tibet during the monsoon (JJA) and back over East Asia after the monsoon (September-October). We have used a threshold of $2.5 \mathrm{~kg} \mathrm{~m}^{-2} \mathrm{~s}^{-1}$ for the upward convective mass flux from the GEOS-5 analyses in the upper troposphere $(350-150 \mathrm{hPa}$ ) to identify the deep convective areas (see contours in Fig. 1). The ASM region is indeed characterized by GEOS-5 upward convective mass-flux values comprised between 1 and $5 \mathrm{~kg} \mathrm{~m}^{-2} \mathrm{~s}^{-1}$ in the upper troposphere (not shown) and $2.5 \mathrm{~kg} \mathrm{~m}^{-2} \mathrm{~s}^{-1}$ corresponds to relatively strong convective uplift. During July and August, high CO UTLS columns are also captured by the model and IASI within the AMA, as has already been documented in Park et al. (2009) and Barret et al. (2008). The AMA is delimited by the $12520 \mathrm{~m}$ geopotential height $(\mathrm{GH})$ contour at the $200 \mathrm{hPa}$ level, as done in Randel and Park (2006) (see Sect. 4.1 for the definition of the AMA boundaries). More specifically, IASI detects enhanced $\mathrm{CO}$ columns in agreement with raw GC columns over the monsoon region and underestimates the $\mathrm{CO}$ columns in the western part of the AMA. This is an effect of IASI's limited vertical sensitivity, as appears from the GC
UTLS distributions once the profiles are smoothed by IASI averaging kernels according to Eq. (1) (Fig. 1 second row) resulting in lower UTLS columns and a better agreement with IASI. This is confirmed by the longitude-pressure cross sections averaged over the $21-29^{\circ} \mathrm{N}$ band that correspond to the southern part of the AMA (Fig. 2), where we notice that the AvK smoothing mixes the UTLS enhanced concentrations throughout the middle and upper troposphere, leading to a better agreement with IASI cross sections. In the eastern part of the AMA, CO UTLS concentrations are higher and better detected by IASI, resulting in a lesser effect of the smoothing and a better agreement between IASI and GC raw columns. Our results apparently disagree with Liu et al. (2013), who report larger underestimations of UTLS GC CO over Asia than elsewhere in July 2005 especially at $100 \mathrm{hPa}$. They argue that this model underestimation probably results from insufficient convective uplift to $100 \mathrm{hPa}$ with GEOS-5. Indeed, our comparisons with IASI (Fig. 1) do not show enhanced underestimation of the GC UTLS columns in the Asian region and in the AMA. The low vertical resolution of IASI and its lack of sensitivity above $150 \mathrm{hPa}$ highlighted in Fig. 2 are probably responsible for this apparent contradiction with Liu et al. (2013).

The good agreement of IASI and GC in the middle and upper troposphere within the enhanced $\mathrm{CO}$ region is confirmed by looking at the latitude-pressure cross sections averaged over the $75-105^{\circ} \mathrm{E}$ longitude domain where convection is 
GC

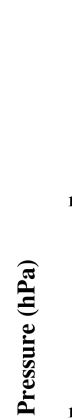

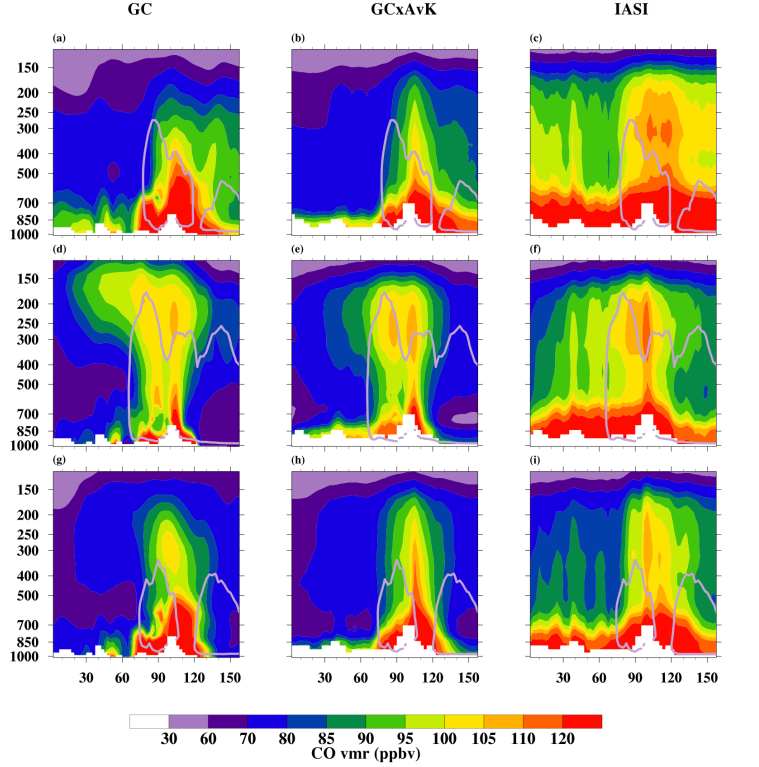

Figure 2. Longitude-pressure cross sections of $\mathrm{CO}$ mixing ratios averaged over $23-29^{\circ} \mathrm{N}$ : (a, d, g) GEOS-Chem; (b, e, h) GEOSChem smoothed with IASI averaging kernels; (c, f, i) IASI. From top to bottom, panels correspond to monthly periods of (a, b, c) May, (d, e, f) July and (g, h, i) October. The grey solid line represents the $2.5 \mathrm{~kg} \mathrm{~m}^{-2} \mathrm{~s}^{-1}$ convective upward mass flux from GEOS-5.

active (Fig. 3). IASI clearly detects the UTLS enhanced CO concentrations between 400 and $200 \mathrm{hPa}$ resulting from convective detrainment in very good agreement with GC. Kar et al. (2004) have already shown that the MOPITT sensor was able to detect UTLS CO enhancements disconnected from the lower troposphere and resulting from convective detrainment during the ASM. Our IASI latitude-pressure cross sections clearly show that IASI is also able to detect such CO UTLS bubbles. Both IASI and GC document that the southern edge of the $\mathrm{CO}$ enhancements shifts from 10 to $20^{\circ} \mathrm{N}$ from May to July and back to $10^{\circ} \mathrm{N}$ from August to October (Fig. 3). Nevertheless, GC underestimates CO throughout the troposphere around $15^{\circ} \mathrm{N}$ particularly in May-June. These results are confirmed by $\mathrm{CO}$ profiles measured by the MOZAIC programme in Hyderabad (Fig. 4). In the middle and upper troposphere, the agreement between MOZAIC and $\mathrm{GC}$ is within the $1 \sigma$ variability, except during the May-June period, characterized by an important $\mathrm{CO}$ underestimation by GC, with nonetheless good modeling of the $\mathrm{CO}$ seasonal variation. Finally, enhanced UTLS CO columns from August to October over Indonesia also correspond with $\mathrm{CO}$ enhanced concentrations between 500 and $200 \mathrm{hPa}$ at the Equator in both IASI and GC distributions in Fig. 3.

Even though the focus of our study is the upper troposphere, we note that, during the May-October period, high $\mathrm{CO}$ concentrations are detected by IASI and simulated by GC in the lower and middle troposphere within the monsoon pol-

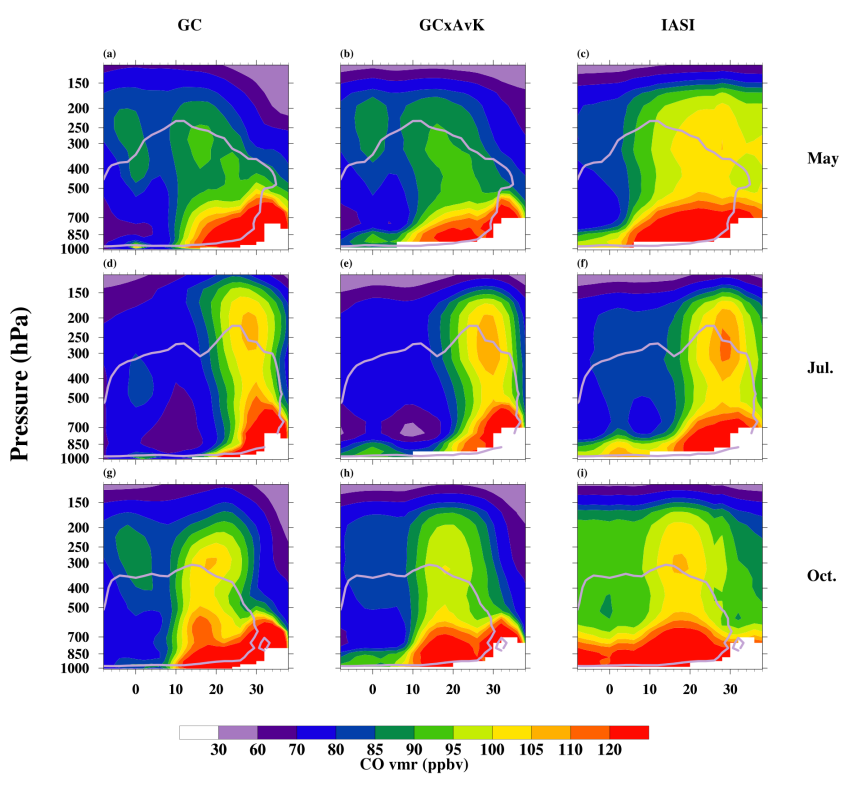

Figure 3. Latitude-pressure cross sections of $\mathrm{CO}$ mixing ratios averaged over $75-105^{\circ} \mathrm{E}$ : (a, d, g) GEOS-Chem; (b, e, h) GEOSChem smoothed with IASI averaging kernels; (c, f, i) IASI. From top to bottom, panels correspond to monthly periods with (a, b, c) May, (d, e, f) July and $(\mathbf{g}, \mathbf{h}, \mathbf{i})$ October. The grey solid line represents the $2.5 \mathrm{~kg} \mathrm{~m}^{-2} \mathrm{~s}^{-1}$ convective upward mass flux from GEOS-5.

luted region over $20-35^{\circ} \mathrm{N}$ (Fig. 3) and $70-120^{\circ} \mathrm{E}$ (Fig. 2). Enhanced $\mathrm{CO}$ concentrations ( $>110 \mathrm{ppbv}$ ) are also detected by IASI west of $70^{\circ} \mathrm{E}$ over the Middle East and northern Africa (Fig. 2) where the model simulates lower CO concentrations even when the model-satellite bias is partly corrected when smoothing by the AvK is taken into account. The smoothing is responsible for mixing high CO concentrations simulated close to the surface to the lower and free troposphere. The discrepancy between GC and IASI in the free troposphere is larger between May and August than in September-October. The study of Liu et al. (2010) also documents an underestimation by GC of TES (Tropospheric Emission Spectrometer) for $\mathrm{CO}$ at $681 \mathrm{hPa}$ over the Middle East and northern Africa that is larger in August than in September and October 2005 (see their Fig. 3). The underestimation of $\mathrm{CO}$ by the GC in the lower and middle troposphere also appears south of $20^{\circ} \mathrm{N}$ in Fig. 3. Comparisons between GC and MOZAIC profiles in Hyderabad (Fig. 4) confirm these overly low CO concentrations simulated by GC below $600 \mathrm{hPa}$ with decreasing differences from June to October.

Concerning the upper troposphere, both GC and IASI are able to capture the seasonal variability associated with the ASM and particularly the CO enhancements within the AMA. It is noteworthy that IASI enables the detection of uplifted CO in the ASM region. Nevertheless, GC significantly underestimates $\mathrm{CO}$ in the lower and middle tropo- 

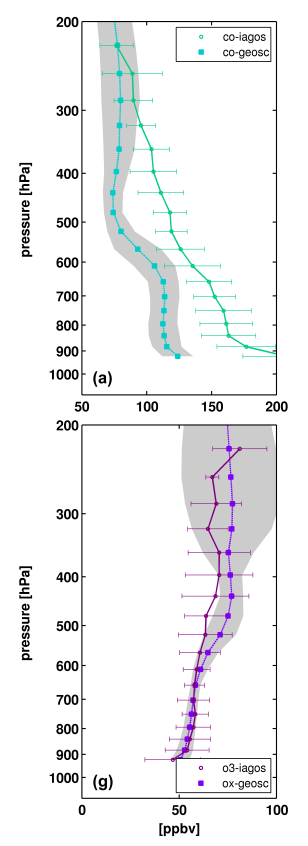
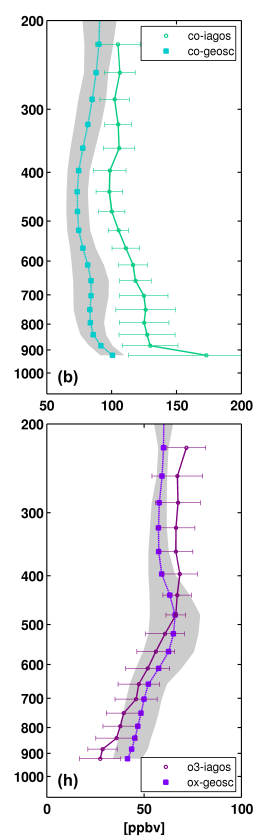
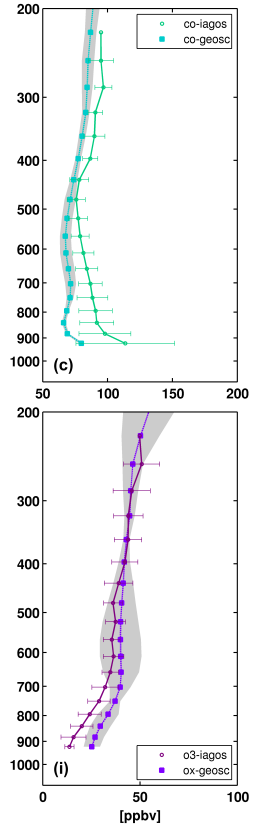
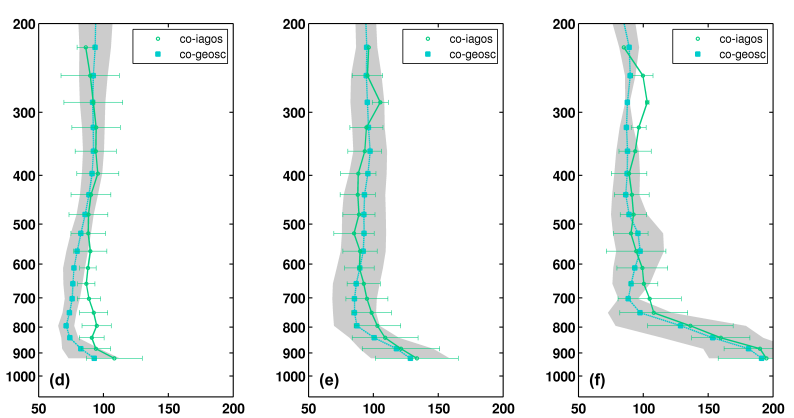

Figure 4. Monthly mean tropospheric vertical profiles of $\mathrm{CO}$ and $\mathrm{O}_{3}$ at Hyderabad $\left(17.2^{\circ} \mathrm{N}, 78.3^{\circ}\right.$ E) from MOZAIC-MOZAIC airborne observations and GEOS-Chem simulations. Top panels: CO from May to October 2009. Bottom panels: $\mathrm{O}_{3}$ from May to August 2009. The grey shadings and the error bars represent the $1 \sigma$ variability for GC and MOZAIC respectively.

Table 1. Statistics of GC vs. IASI UTLS CO and $\mathrm{O}_{3}$ columns comparison over the $10^{\circ} \mathrm{S}-40^{\circ} \mathrm{N}$ and $0-160^{\circ} \mathrm{E}$ domain for monthly averages during the MJJASO period. Figures are given for GC profiles smoothed with the averaging kernels (GCwAvK) and figures in italic between brackets correspond to GC raw data.

\begin{tabular}{rrrr}
\hline & $r$ & Bias & SD \\
$\%$ & $\%$ \\
\hline $\mathrm{CO}$ & $0.70(0.59)$ & $-11.2(-11.4)$ & $9.4(11.8)$ \\
$\mathrm{O}_{3}$ & $0.94(0.93)$ & $-13.8(-19.6)$ & $26.5(32.8)$ \\
\hline
\end{tabular}

sphere during boreal spring over India compared with IASI and MOZAIC.

\section{2 $\mathrm{O}_{3}$ in the Asian troposphere}

Concerning $\mathrm{O}_{3} \mathrm{GC}$ vs. IASI comparisons, it is important to note that using Eq. (1) to smooth GC profiles implies mixing stratospheric $\mathrm{O}_{3}$ concentrations in the UTLS column. The averaging kernels displayed in Barret et al. (2011) show for instance that the $\mathrm{O}_{3}$ concentration retrieved at $150 \mathrm{hPa}$ is sensitive to $\mathrm{O}_{3}$ up to about $50 \mathrm{hPa}$. Stratospheric biases in the model would therefore imply an apparent bias in the modeled UTLS column compared with IASI. As mentioned above, we use GC version 9-01-01, in which stratospheric $\mathrm{O}_{3}$ is based on the linearized scheme from McLinden et al. (2000). Recently Eastham et al. (2014) have evaluated stratospheric $\mathrm{O}_{3}$ from $\mathrm{GC}$ version 9 (using Linoz) vs. a new ver- sion (not publicly available at the time of this study) using the Universal tropospheric-stratospheric Chemistry eXtension (UCX). They show that, averaged annually, GC-Linoz total columns of ozone are biased by 25 to $50 \mathrm{DU}$ compared with TOMS in the band from $40^{\circ} \mathrm{S}$ to $40^{\circ} \mathrm{N}$. The annual averaging hides much larger regional and seasonal discrepancies. Indeed, from their Fig. 2 we can roughly estimate that for the May-October period of interest here, the overestimation of the total columns can reach $100 \mathrm{DU}$ in the tropics and in the Southern Hemisphere, down to $60^{\circ} \mathrm{S}$. From Dufour et al. (2012), we also know that SOFRID stratospheric $\mathrm{O}_{3}$ is highly biased compared to ozonesondes with biases of $8 \pm 5 \%$ for the column up to $30 \mathrm{~km}$ and $7 \pm 5 \%$ for the stratospheric $(16-30 \mathrm{~km})$ column. Comparisons between IASI and GC for the May-October period in the $30^{\circ} \mathrm{S}-30^{\circ} \mathrm{N}$ band show that the mean GC stratospheric (90-24 hPa) column is 1.66 times higher than IASI mean column. Taking the $7 \%$ IASI bias in the tropics into account, we have applied a 0.58 scaling factor to GC profiles in the lower and middle stratosphere (90-24 hPa) before applying the AvK smoothing.

The UTLS $\mathrm{O}_{3}$ columns are displayed in Fig. 5. The most obvious feature of the distributions captured by IASI and $\mathrm{GC}$ is the transition from low columns in the tropical UT south of the tropopause (2PVU) to high columns in the extratropical lower stratosphere. This transition closely follows the undulation of the tropopause. From June to September, the tropopause is pushed northwards by the AMA circulation and the region from the Middle East to East Asia is charac- 

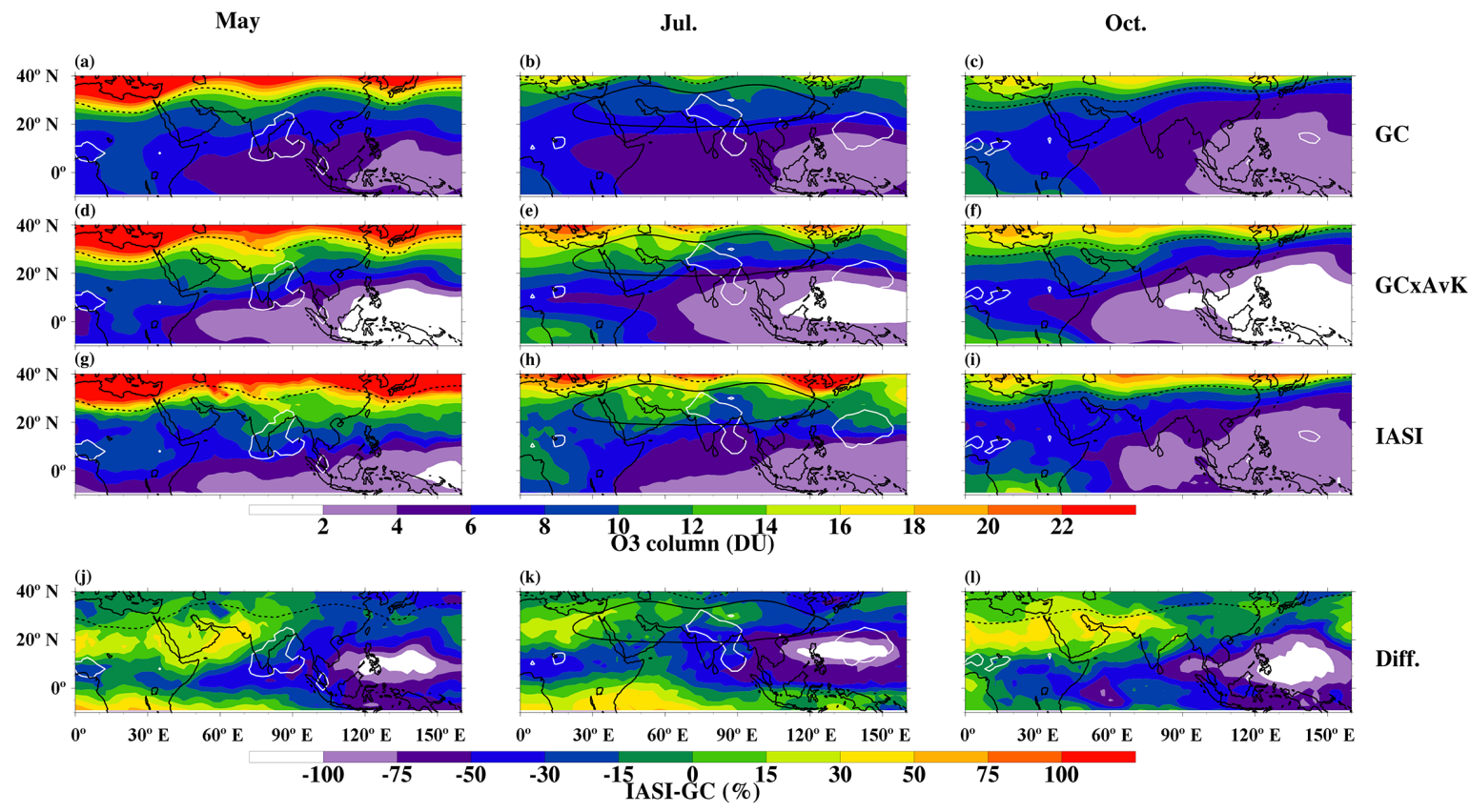

Figure 5. Same as Fig. 1 for $\mathrm{O}_{3}$.

terized by intermediate $\mathrm{O}_{3}$ columns. The region of lowest $\mathrm{O}_{3}$ columns is simulated and observed over the western Pacific in May and progresses northwestwards to Southeast Asia and South India until October. Over Africa, IASI and GC document a southward shift of moderate $\mathrm{O}_{3}$ columns from western Africa in May to southern Africa in September-October. This general good agreement between IASI and $\mathrm{GC} \mathrm{O}_{3}$ distributions translates into correlation coefficients higher than 0.9 and a mean bias of $14 \pm 26 \%$ (see Table 1). Biases between IASI-SOFRID and UTLS columns from ozonesondes were estimated to be $17.5 \pm 19.3 \%$ (Dufour et al., 2012) and $10 \pm 10 \%$ (Barret et al., 2011) once the ozonesondes profiles were smoothed by IASI AvK. The mean value of the GC UTLS columns over our study region is therefore most likely to be in good agreement with ozonesondes. The good behavior of GC UTLS $\mathrm{O}_{3}$ is corroborated by comparisons between GC and MOZAIC profiles at Hyderabad which show a very good agreement between the surface and $200 \mathrm{hPa}$ during the May-August period (see Fig. 4). Unfortunately, no $\mathrm{O}_{3}$ data are available from MOZAIC Hyderabad-Frankfurt flights in September and October 2009.

When smoothing is applied to GC profiles, the features of the $\mathrm{O}_{3}$ distribution remain similar but some corrections are introduced. Over most of the domain, the GC UTLS columns are slightly increased, leading to a better agreement with IASI with differences within $\pm 50 \%$. However, over the oceanic convective regions of the western Pacific characterized by the lowest $\mathrm{O}_{3}$ absolute values, the smoothing tends to decrease the UTLS column, leading to the highest relative biases (exceeding $-50 \%$ ). This decrease of UTLS $\mathrm{O}_{3}$ when
IASI AvK are applied has already been reported in Dufour et al. (2012) for ozonesonde profiles as a result of the accentuation of the $\mathrm{O}_{3} \mathrm{~S}$-shape for tropical profiles. The effect is therefore more important for convective oceanic profiles which have the most marked S-Shape.

The latitude-pressure cross sections displayed in Fig. 6 highlight the impact of the convolution of the modeled profiles by IASI AvK to smooth the lower stratosphere to upper troposphere transition and to decrease the height of the chemical tropopause. The very low $\mathrm{O}_{3}$ concentrations from the model-smoothed profiles over the Bay of Bengal convective region (south of $20^{\circ} \mathrm{S}$ ) result from the accentuation of the S-shape profiles discussed above. These cross sections also indicate the northwards shift of the tropopause and of high UTLS (300-150 hPa) $\mathrm{O}_{3}$ concentrations from May until September. It is interesting to note the large $\mathrm{O}_{3}$ concentrations originating from the stratosphere in the middle troposphere down to $700 \mathrm{hPa}$ between 20 and $30^{\circ} \mathrm{N}$ in May and June that almost disappear in July and August, only to reappear in October. The seasonal variations of STE that both model and observations are pointing to are in good agreement with the results from Cristofanelli et al. (2010) which, based on in situ data in the Himalaya, indicate the absence of stratospheric intrusions during the monsoon season.

Figure 7 presents the $\mathrm{O}_{3}$ longitude-pressure transects over Asia. In the middle-upper troposphere, both model and observations display a persistent west-east gradient with lower $\mathrm{O}_{3}$ concentrations east of $70^{\circ} \mathrm{E}$. This gradient is the highest during the Asian monsoon period when convection is the most active in the western part of the domain and when 


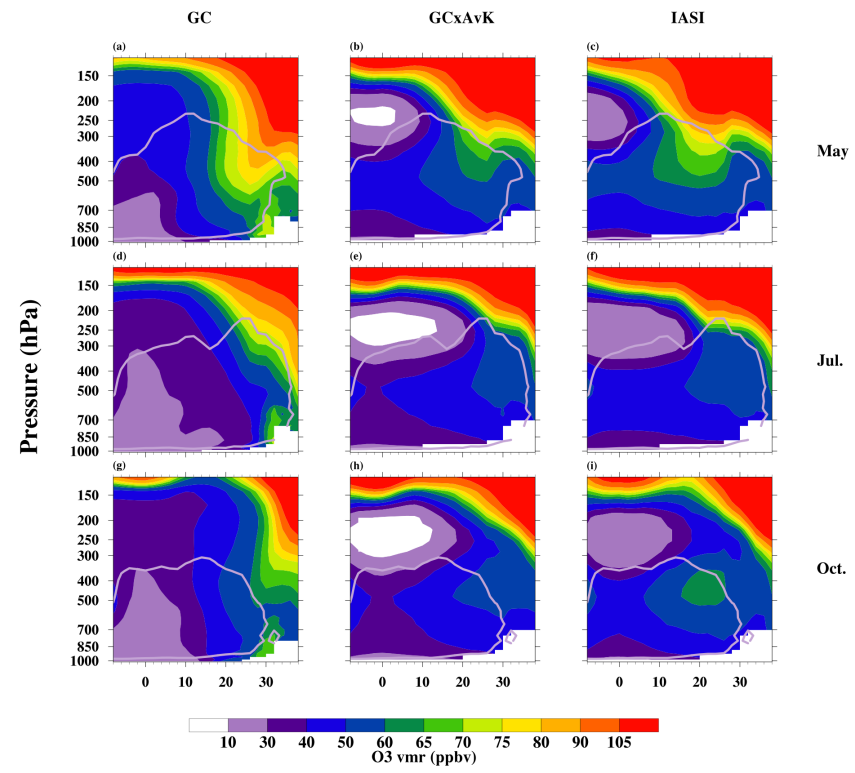

Figure 6. Same as Fig. 3 for $\mathrm{O}_{3}$.

the Middle East is characterized by its annual $\mathrm{O}_{3}$ maximum (Li et al., 2001; Liu et al., 2009, 2013). Nevertheless, from June to September, the UT $\mathrm{O}_{3}$ concentrations are not homogeneously low in the convective region and enhanced $\mathrm{O}_{3}$ concentrations are simulated and observed between 100 and $120^{\circ} \mathrm{E}$. In the model, the lowest $\mathrm{UT} \mathrm{O}_{3}$ concentrations coincide with the deepest convection centered around $75^{\circ} \mathrm{E}$, and the enhanced concentrations coincide with less intense convection, as illustrated by the $2.5 \mathrm{~kg} \mathrm{~m}^{-2} \mathrm{~s}^{-1}$ convective upward mass-flux contour.

The general features of the tropospheric and UTLS O $\mathrm{O}_{3}$ distribution over the large Asian region simulated by the GC are in good agreement with those observed by IASI. The application of the AvK convolution to GC vertical profiles decreases the altitude of the chemical tropopause, smoothes some of the modeled high-resolution features and accentuates the Sshape of convective oceanic $\mathrm{O}_{3}$ profiles. Nevertheless, the model and IASI display the same longitudinal and latitudinal gradients, both in the middle and in the upper troposphere over Asia.

\section{Dynamical and chemical characterization of the AMA}

The first part of this section is dedicated to the characterization of the AMA as a 3-D volume based on dynamical parameters to enable the quantification of chemical budgets within this upper-level anticyclone (Sect. 5). We will then discuss the dominant role played by convection in controlling tropospheric $\mathrm{CO}$ and $\mathrm{O}_{3}$ distributions over Asia and more particularly within the AMA.

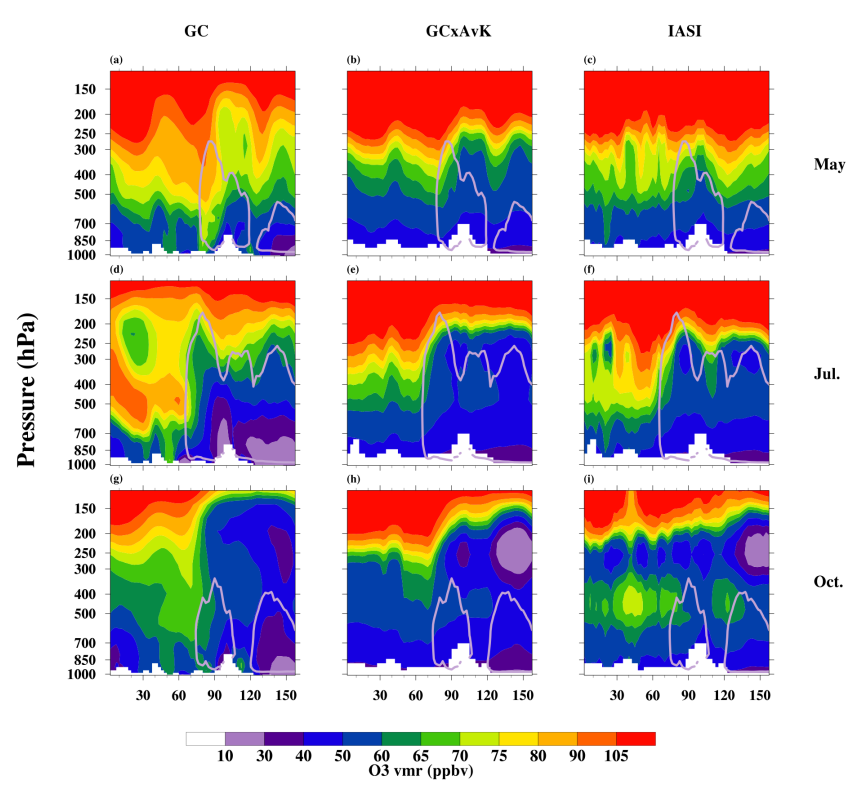

Figure 7. Same as Fig. 2 for $\mathrm{O}_{3}$.

\subsection{The Asian monsoon anticyclone: a 3-D volume}

During May and October, the convective activity mostly takes place over Southeast Asia and the $150 \mathrm{hPa}$ tropopause is located between 30 and $35^{\circ} \mathrm{N}$ over Asia and the AMA is not present (see Fig. 1). In June and September, at the beginning and at the end of the ASM, the convective activity has moved northwards towards the Bay of Bengal and the AMA is present over northeastern South Asia. During the heart of the ASM (July-August), the region impacted by convection encompasses the Bay of Bengal, India, Bangladesh, Nepal and southeastern Tibet and the tropopause is pushed to $40^{\circ}$ north by the AMA, which is fully developed and extends roughly from 20 to $40^{\circ} \mathrm{N}$ and from 30 to $120^{\circ} \mathrm{E}$ and vertically from 300 to $100 \mathrm{hPa}$. The center of the AMA is bimodal with the high-pressure center located alternatively over the Tibetan plateau and over Iran (Zhang et al., 2002). This high-level anticyclone is characterized by large-scale periodic elongations and shedding as described in Popovic and Plumb (2001). The AMA air masses are characterized by low potential vorticity (PV) values or high GHs. Based on MLS CO analyses, Barret et al. (2008) have shown that daily $\mathrm{CO}$ and $\mathrm{PV}$ variations were strongly correlated with low PV related to high CO. In the Asian UTLS, the tracer concentration is therefore strongly controlled by the oscillations and shedding of the AMA. In their study of the AMA strength and variability, Garny and Randel (2013) also pointed to the spatiotemporal correlation of $\mathrm{CO}$ enhancements and low PV values which is stronger in the upper levels of the AMA. Based on PV fields Ploeger et al. (2015) have developed a method to characterize the dynamical barrier that delimit the inside and the outside of the AMA on a daily timescale. The 

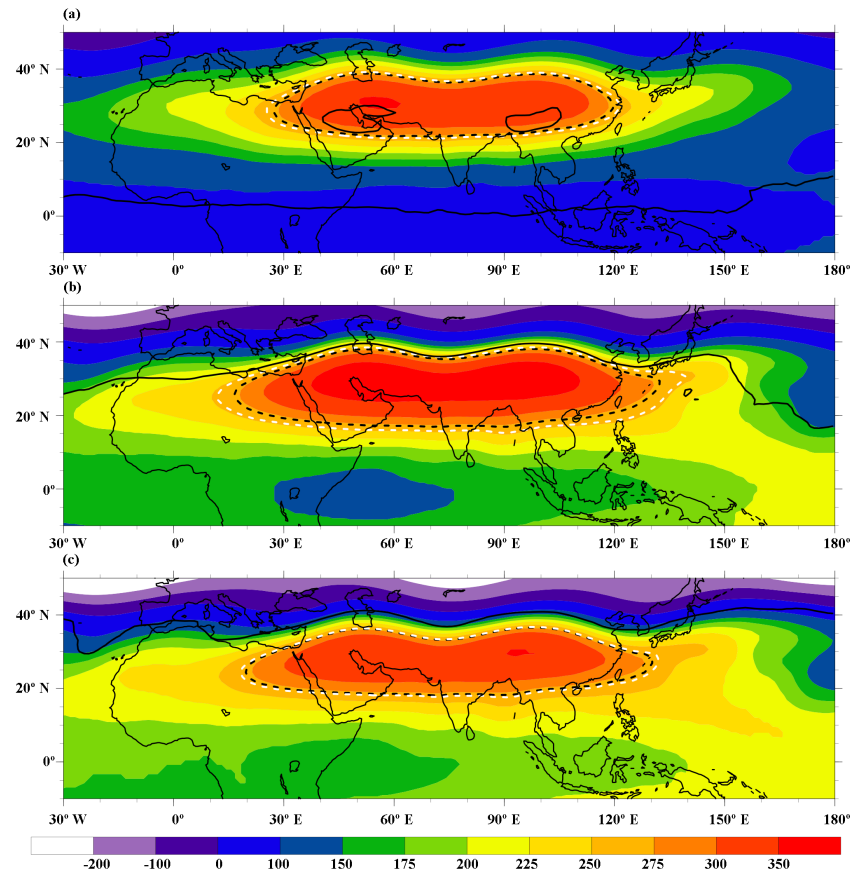

Figure 8. Geopotential heights (GH) from MERRA for July 2009 at (a) 100, (b) $150 \mathrm{hPa}$ and (c) $200 \mathrm{hPa}$. The black dotted lines represent the GH isocontours at (a) $16770 \mathrm{~m}$, (b) $14350 \mathrm{~m}$ and (c) $12520 \mathrm{~m}$ and the white dotted line represents the $270 \mathrm{~m} \mathrm{GH}$ anomalies (see text for details).

boundaries of the AMA based on their method are consistent with tracer concentrations (high $\mathrm{CO}$ and low $\mathrm{O}_{3}$ within the AMA). In studies looking at monthly or seasonal timescales, the edge of the AMA has been mostly defined as simple constant GH contours at different pressure levels. Randel and Park (2006) (Heath and Fuelberg, 2014) use a 14320 (14 430) $\mathrm{m} \mathrm{GH}$ for the AMA at $150 \mathrm{hPa}$ and Bergman et al. (2013) use 12520 (16770) $\mathrm{m} \mathrm{GH}$ at 200 (100) hPa.

In order to determine the $\mathrm{CO}$ and $\mathrm{O}_{3}$ budget within the AMA, we first need to characterize the AMA as a closed volume and we have therefore looked for a criterion independent of the pressure level. As already discussed, the studies based on PV (Barret et al., 2008; Garny and Randel, 2013; Ploeger et al., 2015) have shown that it was a good dynamical parameter to characterize the AMA high-frequency variability whilst GH was mostly used on monthly timescales (Randel and Park, 2006; Bergman et al., 2013; Heath and Fuelberg, 2014). Furthermore, Ploeger et al. (2015) is the only study that proposes a PV-based criterion to delimit the AMA but this criterion is only defined and validated for the $380 \mathrm{~K}$ potential temperature level $(\sim 200 \mathrm{hPa})$. As the PV tracer relationship is stronger at the higher levels $(380 \mathrm{~K})$ of the AMA (Garny and Randel, 2013) the criterion from Ploeger et al. (2015) may not hold for the lower levels. Finally, on monthly timescales, simple GH thresholds have been shown to consistently delimit regions of tracer anomalies characteristic
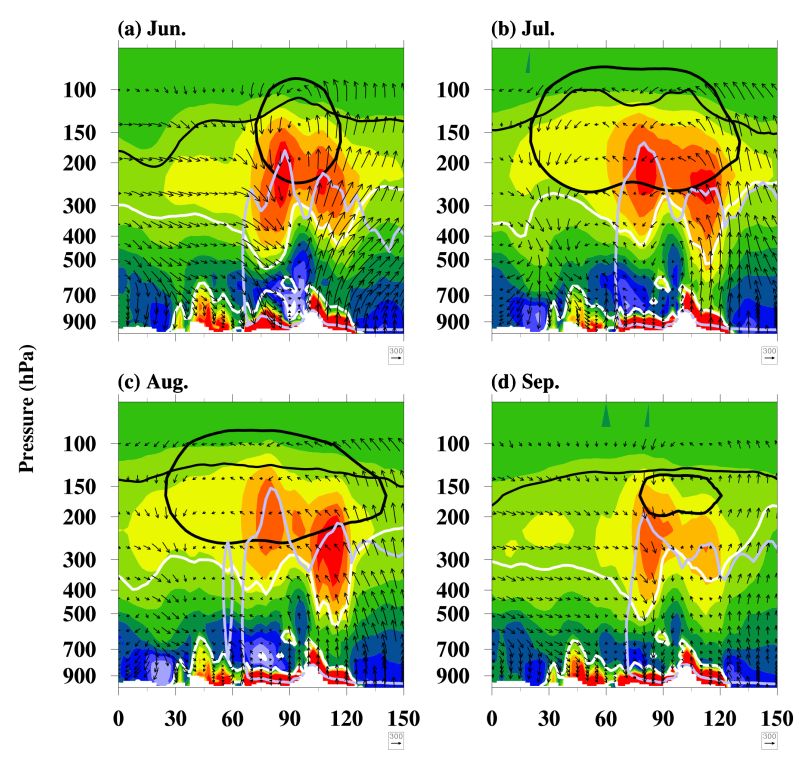

$$
\begin{array}{ccccccccccc}
-5 & -4 & -3 & -2 & -1 & 0 & 1 & 2 & 3 & 4 & 5 \\
03 & \text { Oet Prod. (ppbv day }
\end{array}
$$

Figure 9. Longitude-pressure cross sections of $\mathrm{GC}$ simulated $\mathrm{O}_{3}$ net production rates averaged over $23-29^{\circ} \mathrm{N}$ in (a) June, (b) July, (c) August and (d) September 2009. The black arrows correspond to the $\mathrm{O}_{3}$ fluxes and the white solid lines to the 100 pptv $\mathrm{NO}_{x}$ contours from GC. The dashed black line corresponds to the tropopause (2 PVU), the grey solid line to upward convective mass fluxes of $2.5 \mathrm{~kg} \mathrm{~m}^{-2} \mathrm{~s}^{-1}$ at $200 \mathrm{hPa}$ and the black solid line to the AMA boundary computed as the $270 \mathrm{~m} \mathrm{GH}$ anomaly (see text for details).

of the AMA at different pressure levels. We have therefore chosen to use a criterion based on GH rather than PV to delimit the AMA. Our criterion is based on thresholds of GH anomalies. We use the GH monthly fields from the MERRA re-analyses, which are provided on 42 levels from the surface to $0.1 \mathrm{hPa}$ with a $1.25^{\circ} \times 1.25^{\circ}$ horizontal resolution. The anomalies are computed as the differences between the mean zonal $\mathrm{GH}$ computed over the $50^{\circ} \mathrm{N}$ to $50^{\circ} \mathrm{S}$ latitudinal band and the local GH. The AMA appears very clearly at different UTLS levels as the region with the highest GH anomalies on Fig. 8. The contours corresponding to a $270 \mathrm{~m}$ $\mathrm{GH}$ anomaly best match the 16770,14320 and $12520 \mathrm{~m} \mathrm{GH}$ isocontours at 100,150 and $200 \mathrm{hPa}$ corresponding to the AMA edge in Bergman et al. (2013), Randel and Park (2006) and Bergman et al. (2013), respectively. We have therefore chosen a $270 \mathrm{~m} \mathrm{GH}$ anomaly as the threshold for the AMA boundary throughout the UTLS. In Sect. 5, within the AMA and outside of the AMA both refer to the tropospheric part of these atmospheric regions bounded by the $2 \mathrm{PVU}$ contour. 


\subsection{Relationship between convection and the $\mathrm{CO}$ and $\mathrm{O}_{3}$ distributions}

The studies presented in the introduction have highlighted the AMA as a region with a composition that is very different from its surroundings, according to UTLS satellite observations. The use of IASI data brings information about $\mathrm{CO}$ and $\mathrm{O}_{3}$ over the whole troposphere and therefore allows us to better document the link between the upper-tropospheric distributions and transport processes such as convection. In the following paragraph, we analyze the modeled and observed $\mathrm{O}_{3}$ and $\mathrm{CO}$ distributions in light of their relationship with convection.

In the middle troposphere, the longitude-pressure sections of $\mathrm{CO}$ and $\mathrm{O}_{3}$ presented above are anti-correlated. East of about $80^{\circ} \mathrm{E}$, in the monsoon region characterized by the strongest convective upward mass fluxes from GEOS5 , high $\mathrm{CO}(90 \mathrm{ppbv})$ is associated with low $\mathrm{O}_{3}(60 \mathrm{ppbv})$ and west of $80^{\circ} \mathrm{E}$ low $\mathrm{CO}$ is associated with high $\mathrm{O}_{3}$. This anti-correlation is clear both from the model outputs and from IASI data. The high summer tropospheric $\mathrm{O}_{3}$ extending from western India to northern Africa has been first described as the"Middle East tropospheric ozone maximum" by Li et al. (2001) and further analyzed by Liu et al. (2009, 2010). The subsidence associated with the AMA is taking place in the middle troposphere on its western side over the Eastern Mediterranean, the Middle East and Central Asia (Hoskins and Rodwell, 1995; Liu et al., 2009). This phenomenon is clearly seen in Fig. 9, which displays $\mathrm{GC} \mathrm{O}_{3}$ fluxes in a longitude-pressure cross section at the center of the AMA. This descent of air masses impacted by Asian pollution trapped within the AMA contributes to the summer "Middle East tropospheric ozone maximum". In their analysis, Liu et al. (2009) have shown that the $\mathrm{O}_{3}$ buildup is favored by the Arabian and Saharan anticyclones that isolate the middle troposphere over this region. From simulations with tagged $\mathrm{O}_{3}$, Liu et al. $(2009,2010)$ attribute an equivalent and dominant impact (30-35\%) on the $\mathrm{O}_{3}$ maximum over the Middle East to local sources and transport from Asia via the UT and the AMA circulation. Over northern Africa, transport from Asia contributes less than regional sources. It is clear from the CO GC distributions displayed by Liu et al. (2009) (their Fig. 6) and from the present study as well as from our IASI data (Figs. 2 and 7) that the $\mathrm{O}_{3}$ Middle East maximum in the middle troposphere coincides with relatively low $\mathrm{CO}$ concentrations.

Between 80 and $120^{\circ} \mathrm{E}$, the low $\mathrm{O}_{3}$ and high $\mathrm{CO}$ concentrations result from the convective activity occurring in South and Southeast Asia during the monsoon. Convection mixes $\mathrm{CO}$ between the Asian polluted PBL and the upper troposphere, resulting in enhanced concentrations over the whole troposphere. The overlap between important $\mathrm{CO}$ sources and convection occurs primarily over the Indo-Gangetic Plain (IGP) according to Fig. 10, which displays anthropogenic $\mathrm{CO}$ emissions from the Streets inventory (Streets et al., 2006)

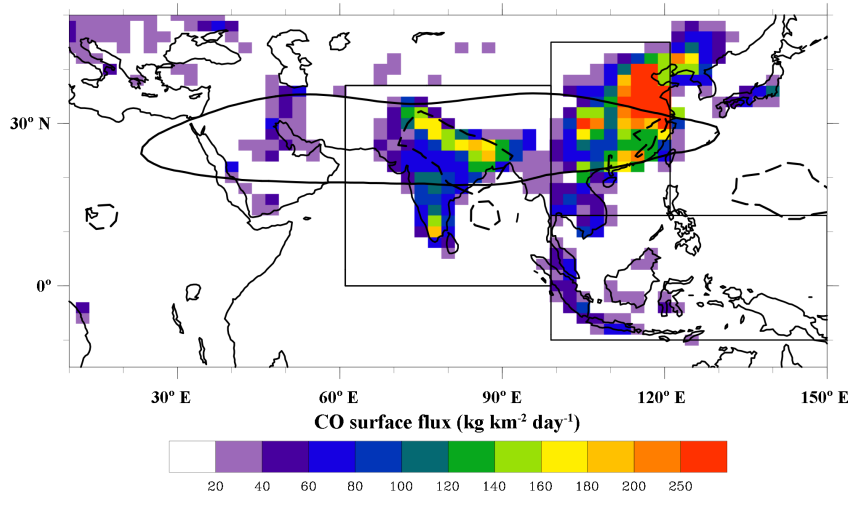

Figure 10. Anthropogenic emissions of CO from the Streets 2006 inventory for July. The black dashed line is the $2.5 \mathrm{~kg} \mathrm{~m}^{-2} \mathrm{~s}^{-1}$ convective upward mass flux contour at $2225 \mathrm{hPa}$ from GEOS-5 for July 2009 and the solid black line is the $12520 \mathrm{~m} \mathrm{GH}$ contour from MERRA at $200 \mathrm{hPa}$ for July 2009. The three boxes correspond to the regions selected for the sensitivity simulations with anthropogenic emissions switched off (South, East and Southeast Asia).

and GEOS-5 upward convective mass fluxes. The impact of convective transport on the $\mathrm{O}_{3}$ distribution is more complicated. It results from two antagonist effects: the vertical mixing of $\mathrm{O}_{3}$ itself and the uplift of $\mathrm{O}_{3}$ precursors followed by enhanced photochemical $\mathrm{O}_{3}$ production (Doherty et al., 2005; Lawrence et al., 2003). The vertical mixing results in the transport of $\mathrm{O}_{3}$-poor air masses from the lower troposphere, where $\mathrm{O}_{3}$ lifetime is short, to the upper troposphere, where it is long, and the transport of $\mathrm{O}_{3}$-rich air masses from the upper to the lower troposphere by compensatory subsidence. The effect of this overturning is a decrease of UT $\mathrm{O}_{3}$ and of the tropospheric $\mathrm{O}_{3}$ burden and lifetime. Over polluted regions, such as Asia, convection uplifts $\mathrm{O}_{3}$ precursors (especially $\mathrm{NO}_{x}$ ) result in an increase of the $\mathrm{O}_{3}$ production in the middle and upper troposphere at the expense of the lower troposphere. The electric activity from convective storms is responsible for the in situ production of $\mathrm{LiNO}_{x}$, also responsible for an increased $\mathrm{O}_{3}$ production. This source of $\mathrm{O}_{3}$ clearly appears in Fig. 9 where the net $\mathrm{O}_{3}$ production rates are enhanced between 500 and $150 \mathrm{hPa}$ in the monsoon region. Convective clouds also diminish the tropospheric photochemical activity through a reduction of the solar UV radiations. These combined effects are responsible for the lower mid-tropospheric $\mathrm{O}_{3}$ concentrations over South Asia compared to regions with high insolation and downward transport of $\mathrm{O}_{3}$, such as the Middle East and northern Africa.

In the Asian upper troposphere in June, the AMA builds up and only extends between 60 and $120^{\circ} \mathrm{E}$ and the $\mathrm{O}_{3}$ fluxes switch from downward to upward around $90^{\circ} \mathrm{E}$ (Fig. 9). In July and August, the AMA is well established over the 15$145^{\circ} \mathrm{E}$ domain and the upward flux remains east of $90^{\circ} \mathrm{E}$ in the monsoon region while the strongest downward fluxes move to the western edge of the AMA between 15 and $45^{\circ} \mathrm{E}$. 
As already discussed, this downward flux partly contributes to the buildup of the Middle East $\mathrm{O}_{3}$ maximum as described in Liu et al. (2009). In September, the situation is similar to June: the AMA has largely shrunk and the $\mathrm{O}_{3}$ production is associated with an $\mathrm{O}_{3}$ downward flux between 75 and $90^{\circ} \mathrm{E}$. Above the continents, the photochemistry illustrated by the $\mathrm{O}_{3}$ net production rates in Fig. 9 switches from a net source of $\mathrm{O}_{3}$ in the polluted PBL to a net sink in the free troposphere below about $500 \mathrm{hPa}$ and again to a net production in the middle and upper troposphere. This behavior agrees with the different $\mathrm{NO}_{x}$ photochemical regimes discussed in Jacob et al. (1996). In particular, low $\mathrm{NO}_{x}$ concentrations are responsible for the destruction of $\mathrm{O}_{3}$ in the lower and middle troposphere and slightly higher concentrations produce $\mathrm{O}_{3}$ in the upper troposphere, as explained in Brune (1992; IGAC Report). During the whole period, the $\mathrm{O}_{3}$ net production pattern in the middle and upper troposphere is characterized by a double maximum with values exceeding $5 \mathrm{ppbv}$ day $^{-1}$, which are associated with the upward fluxes east of $90^{\circ} \mathrm{E}$ and downward fluxes (except in August) west of $90^{\circ}$ E. Both upper troposphere maxima are located within the eastern half of the AMA. Below the tropopause, the $\mathrm{O}_{3}$ net production rate exceeds 2 ppbv day ${ }^{-1}$ within the whole AMA. The enhanced net $\mathrm{O}_{3}$ production rates are associated with enhanced $\mathrm{NO}_{x}$ concentrations (100 pptv contour in white). In the upper troposphere, the AMA therefore appears as a region of high $\mathrm{O}_{3}$ production, resulting from the trapping of $\mathrm{NO}_{x}$ from various sources. In the next section, we determine the impact of the different sources on the $\mathrm{CO}$ and $\mathrm{O}_{3}$ budgets within the AMA.

\section{$5 \mathrm{CO}$ and $\mathrm{O}_{3}$ budget}

Our aim here is to characterize the origin of $\mathrm{CO}$ and $\mathrm{O}_{3}$ within the Asian upper troposphere during the monsoon season by comparing the impact of the different emission sources inside and outside of the AMA based on sensitivity simulations for the different type of emissions and for the different regions of interest. For $\mathrm{CO}$ we have considered anthropogenic and $\mathrm{BB}$ emissions and for $\mathrm{O}_{3}$ we have considered the production of $\mathrm{NO}_{x}$ originating from anthropogenic, $\mathrm{BB}$ and lightning sources and the transport of stratospheric $\mathrm{O}_{3}$ through STE.

\subsection{The CO budget}

As mentioned in Sect. 2.3, we have considered the two main regions of importance concerning anthropogenic $\mathrm{CO}$ emissions: South and East Asia. Park et al. (2009) and Yan and Bian (2015) have indeed highlighted the predominant role of Asian sources from these two regions in filling the AMA with $\mathrm{CO}$. We can also notice that the surface fluxes of $\mathrm{CO}$ used for our GC simulations (Fig. 10) are the largest for the whole Asian region over northeastern China and for the South Asian domain over the IGP. These fluxes are consistent with those

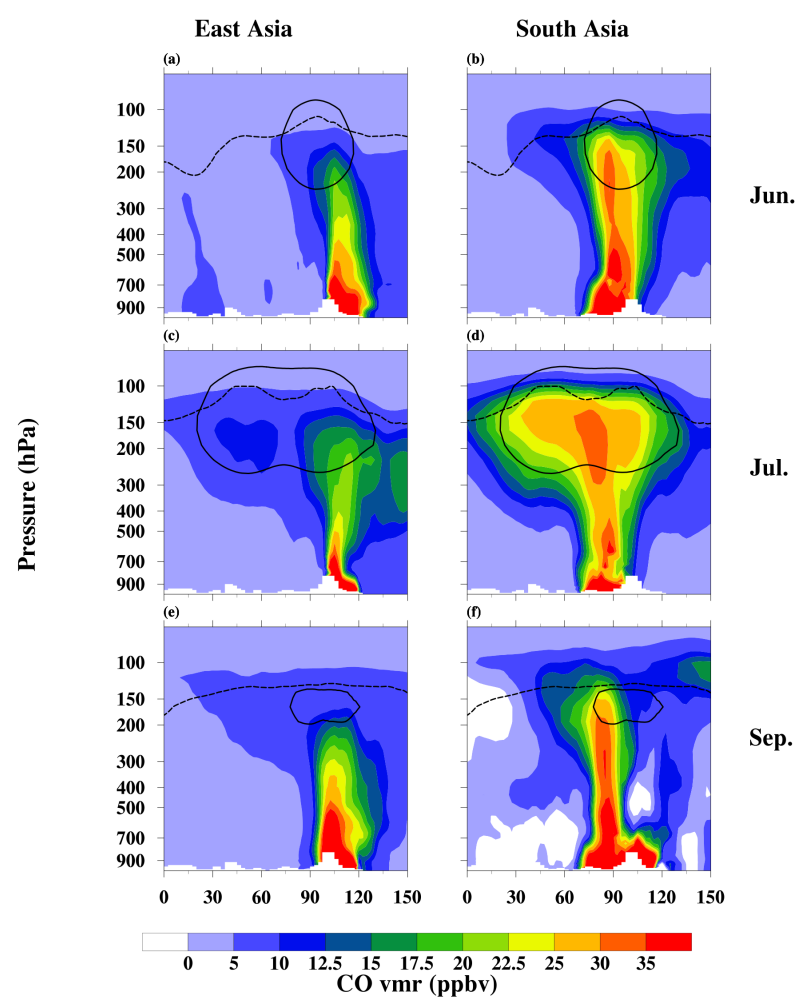

Figure 11. Longitude-pressure cross sections of the sensitivity of $\mathrm{CO}$ to anthropogenic $\mathrm{CO}$ sources averaged over $23-29^{\circ} \mathrm{N}$ from (a, c, e) East Asia and $(\mathbf{b}, \mathbf{d}, \mathbf{f})$ South Asia computed as the differences between the control run and simulations with the corresponding source switched off. From top to bottom, panels correspond to (a, b) June, (c, d) July and (e, f) September 2009.

used in Park et al. (2009) and Yan and Bian (2015). Concerning BB, Nassar et al. (2009) have shown that Indonesian BB emissions had a large impact on the Indian uppertropospheric composition in 2006 following the perturbation of the tropical circulation by a strong El Niño event. Our sensitivity simulations performed for Indonesian or Southeast Asian anthropogenic sources have shown that in 2009 this region did not impact the South Asian upper troposphere (not shown). The simulation with African BB CO emissions switched off also results in negligible modifications of the CO distribution in the South Asian upper troposphere (not shown).

The differences between the reference simulation and the sensitivity simulations with anthropogenic $\mathrm{CO}$ emissions from South and East Asia shut down are displayed in Fig. 11 for the pressure-longitude section $\left(21-29^{\circ} \mathrm{N}\right)$ and in Fig. 12 for the upper-tropospheric $(200 \mathrm{hPa})$ distribution. The average $\mathrm{CO}$ mixing ratio differences between on and off simulations within and outside of the AMA are given in Table 2. The pressure-longitude sections clearly show that the upper troposphere and especially the AMA ones are more impacted by South Asian than East Asian emissions. For the 4 months 
Table 2. Monthly CO from different sources inside and outside of the AMA in ppbv.

\begin{tabular}{lrrrrr}
\hline & \multicolumn{2}{c}{$\begin{array}{c}\text { Anthropic } \\
\text { East Asia }\end{array}$} & & \multicolumn{2}{c}{$\begin{array}{c}\text { Anthropic } \\
\text { South Asia }\end{array}$} \\
\cline { 2 - 3 } \cline { 6 - 7 } & AMA & Out & & AMA & Out \\
\hline June & 8.3 & 5.3 & & 17.3 & 10.1 \\
July & 10.7 & 8.9 & & 25.3 & 13.8 \\
August & 9.9 & 10.0 & & 23.7 & 15.9 \\
September & 7.8 & 7.4 & & 14.3 & 8.2 \\
\hline
\end{tabular}

considered, $\mathrm{CO}$ from South Asia is responsible for $\mathrm{CO}$ enhancements of 20 to $30 \mathrm{ppbv}$ within the AMA between 300 and $100 \mathrm{hPa}$, while East Asian emissions mostly impact regions below $200 \mathrm{hPa}$ on the eastern side of the AMA. This result is expected from the correlation between high emissions and strong convection over South Asia as can be seen in Fig. 10. High convective mass fluxes $\left(>2.5 \mathrm{~kg} \mathrm{~m}^{-2} \mathrm{~s}^{-1}\right)$ at $225 \mathrm{hPa}$ are located over the IGP, where CO emission fluxes exceed $150 \mathrm{~kg} \mathrm{~km}^{-2} \mathrm{day}^{-1}$. East of the Himalaya, the emissions are largest over eastern China where convection is not as strong as over the IGP. The region with the strongest South Asian CO uplift in the middle troposphere lies between 75 and $105^{\circ} \mathrm{E}$ according to the GC (see Fig. 11), which is consistent with Bergman et al. (2013), who highlights that PBL air masses that reach the UTLS pass through a midtropospheric conduit located roughly over the same region.

In the upper troposphere at $200 \mathrm{hPa}$, East Asian emissions are only responsible for $\mathrm{CO}$ enhancements of about 10-20 ppbv located over Southeast Asia and China during the monsoon. Larger $\mathrm{CO}$ enhancements are caused by South Asian emissions with the highest values ( $>35 \mathrm{ppbv}$ ) located within the convective region around $75^{\circ} \mathrm{E}$ and $27^{\circ} \mathrm{N}$ and values exceeding $20 \mathrm{ppbv}$ that spread within the AMA bounded by the tropopause to the north. These values are higher than those of Yan and Bian (2015), who found CO enhancements of $12-30 \mathrm{ppbv}$ from Indian sources and of 5-9 ppbv from Chinese sources at $215 \mathrm{hPa}$. At $100 \mathrm{hPa}$ (not shown), East Asian sources contribute to less than $6 \mathrm{ppbv}$ to UTLS CO, which is slightly lower than what Yan and Bian (2015) and Park et al. (2009) have documented. Concerning South Asian sources, they are responsible for 12 to 20 ppbv CO enhancements (not shown) in good agreement with Yan and Bian (2015) and Park et al. (2009). Vogel et al. (2015) have also quantified the origin of PBL air masses in the AMA using artificial emission tracers from the CLaMS CTM. Their emission regions are different from those used in the present study. India is separated into northern and South India and Southeast Asia encompasses our Southeast Asia and part of our East Asia (most of the Indochinese peninsula). Nevertheless, their results show some agreement with ours and give some complementary information. They show that when the AMA is established, PBL air masses coming from northern

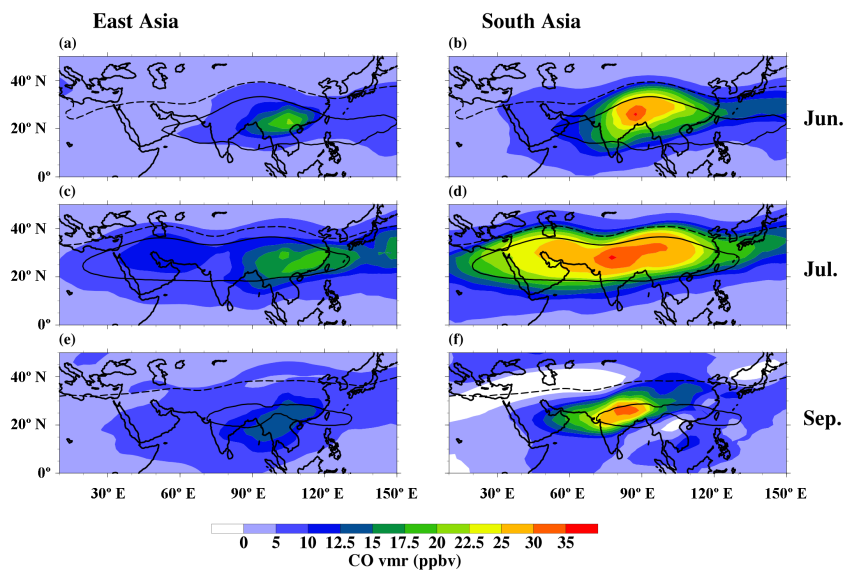

Figure 12. Same as in Fig. 11 for the distributions at $200 \mathrm{hPa}$.

India fill up the AMA comparably to our South Asian tracer, which indicates that South India plays a minor role. Their Southeast Asian emission tracer is transported upwards and remains at the edge of the AMA such as our East Asian tracer (especially for August, which is not shown). The agreement probably comes from the fact that both tracers encompasses the Indochinese peninsula where convection is strong during the monsoon but which is located to the south of the AMA.

The average figures of Table 2 summarize these results. South Asian CO emissions are responsible for a strong CO enhancement within the AMA from June to September with a maximum of $\sim 25 \mathrm{ppbv}$ during the monsoon peak in JulyAugust. Furthermore, average CO enhancements from South Asian emissions are about 10 ppbv larger within than outside of the AMA, which further highlights the AMA as a trap for uplifted South Asian pollution during the monsoon. East Asian emissions result in maximum enhancements of about $10 \mathrm{ppbv}$ in the UTLS during July-August. The little differences between the enhancements computed within and outside of the AMA also show that East Asian sources are located outside of the conduit connecting boundary layer air masses and the AMA described in Bergman et al. (2013).

\subsection{The $\mathrm{O}_{3}$ budget}

The contribution to the $\mathrm{O}_{3}$ burden from the main sources of $\mathrm{NO}_{x}$ emissions is computed from sensitivity simulations with the GC model. Sauvage et al. (2007b) have shown that tropospheric $\mathrm{O}_{3}$ over Asia during the monsoon is mostly impacted by Asian sources. Focusing on the Indian region, Kunhikrishnan et al. (2006) have also highlighted the predominance of Asian sources (India, China and Indonesia) on the Indian tropospheric $\mathrm{O}_{3}$ budget during the monsoon. They have also shown that Middle East emissions have a small impact on $\mathrm{NO}_{x}$ and $\mathrm{O}_{3}$ concentrations below $500 \mathrm{hPa}$ and that African and Middle East sources have a negligible impact in the middle and upper troposphere over India during the 
Table 3. Monthly $\mathrm{O}_{3}$ and $\mathrm{NO}_{x}$ from different sources inside and outside of the AMA in ppbv. The values for $\mathrm{NO}_{x}$ are given in brackets.

\begin{tabular}{|c|c|c|c|c|c|c|c|c|c|c|}
\hline & \multicolumn{2}{|c|}{$\begin{array}{l}\text { Anthropic } \\
\text { East Asia }\end{array}$} & \multicolumn{2}{|c|}{$\begin{array}{l}\text { Anthropic } \\
\text { South Asia }\end{array}$} & \multicolumn{2}{|c|}{$\begin{array}{c}\mathrm{LiNO}_{x} \\
\text { Asia }\end{array}$} & \multicolumn{2}{|c|}{$\begin{array}{l}\mathrm{LiNO}_{x} \\
\text { Africa }\end{array}$} & \multicolumn{2}{|c|}{ Strato. } \\
\hline & AMA & Out & AMA & Out & AMA & Out & AMA & Out & AMA & Out \\
\hline \multirow[t]{2}{*}{ June } & 3.3 & 2.0 & 4.6 & 2.0 & 9.5 & 6.3 & 3.6 & 5.4 & 11.8 & 9.6 \\
\hline & $(0.027)$ & $(0.010)$ & $(0.025)$ & $(0.012)$ & $(0.11)$ & $(0.05)$ & $(0.019)$ & $(0.005)$ & & \\
\hline \multirow[t]{2}{*}{ July } & 5.2 & 4.6 & 7.6 & 4.7 & 13.5 & 7.2 & 1.0 & 1.5 & 10.0 & 5.9 \\
\hline & $(0.033)$ & $(0.021)$ & $(0.043)$ & $(0.017)$ & $(0.129)$ & $(0.048)$ & $(0.012)$ & $(0.018)$ & & \\
\hline \multirow[t]{2}{*}{ August } & 4.9 & 5.2 & 8.1 & 4.4 & 9.9 & 5.3 & 0.9 & 1.2 & 6.7 & 3.9 \\
\hline & $(0.027)$ & $(0.023)$ & $(0.042)$ & $(0.016)$ & $(0.087)$ & $(0.036)$ & $(0.011)$ & $(0.022)$ & & \\
\hline \multirow[t]{2}{*}{ September } & 3.4 & 3.3 & 5.2 & 4.0 & 6.1 & 5.0 & 1.1 & 2.2 & 6.7 & 4.7 \\
\hline & $(0.018)$ & $(0.014)$ & $(0.033)$ & $(0.018)$ & $(0.074)$ & $(0.044)$ & $(0.010)$ & $(0.032)$ & & \\
\hline
\end{tabular}

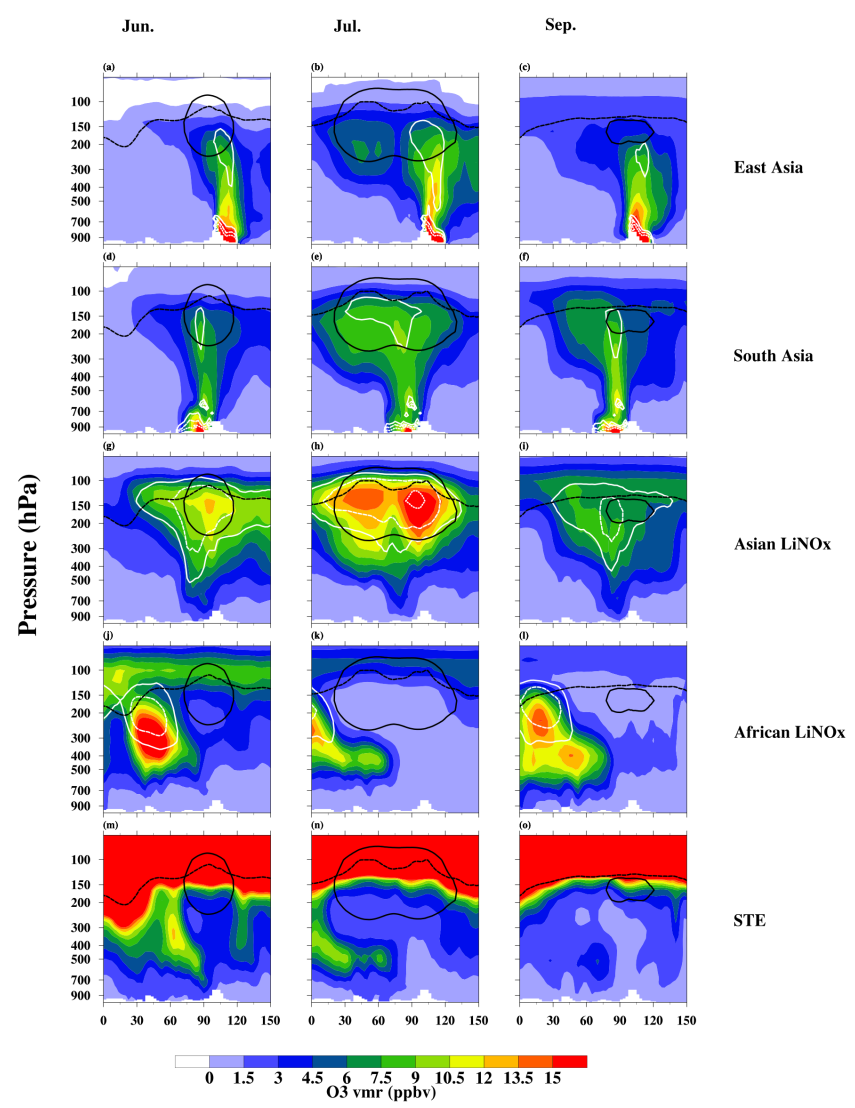

Figure 13. Longitude-pressure cross sections of the sensitivity of $\mathrm{O}_{3}$ to $\mathrm{NO}_{x}$ sources averaged over $23-29^{\circ} \mathrm{N}$ for $(\mathbf{a}, \mathbf{b}, \mathbf{c})$ East Asian anthropogenic, (d, e, f) South Asian anthropogenic, (g, h, i) Asian lightning and $(\mathbf{j}, \mathbf{k}, \mathbf{l})$ African lightning computed as the difference between the control run and simulations with the corresponding source switched off. Panels $(\mathbf{m}, \mathbf{n}, \mathbf{o})$ correspond to tagged stratospheric $\mathrm{O}_{3}$ to diagnose STE. From left to right, panels correspond to monthly means with (a, d, $\mathbf{g}, \mathbf{j}, \mathbf{m})$ June, $(\mathbf{b}, \mathbf{e}, \mathbf{h}, \mathbf{k}, \mathbf{n})$ July and (c, f, i, l, o) September 2009. The white solid, dashed and dotted lines correspond to the 50, 100 and 200 pptv contours, respectively, for the sensitivity of $\mathrm{NO}_{x}$ to the different $\mathrm{NO}_{x}$ sources.
ASM. We have therefore chosen to focus on the impact of Asian emissions upon the $\mathrm{AMA} \mathrm{O}_{3}$ burden. Concerning anthropogenic emissions, we have separated Asia into the same three main regions as for $\mathrm{CO}$ (see Sect. 2.3). One of the main conclusions of Sauvage et al. (2007b) is that $\mathrm{LiNO}_{x}$ is the most important $\mathrm{NO}_{x}$ source controlling the tropical tropospheric $\mathrm{O}_{3}$ burden. We therefore performed simulations to characterize the importance of $\mathrm{LiNO}_{x}$ from the two nearby monsoon regions (see Sect. 2.3) upon upper-tropospheric $\mathrm{O}_{3}$ during the ASM. Finally, the impact of STE was established using the $\mathrm{GC}$ stratospheric $\mathrm{O}_{3}$ tagged tracer as explained in Sect. 2.3.

For $\mathrm{O}_{3}$, the results of the sensitivity simulations are displayed in Fig. 13 for longitude-pressure sections averaged over the $21-29^{\circ} \mathrm{N}$ band and in Fig. 14 for maps at $200 \mathrm{hPa}$. The results are summarized in Table 3 for $\mathrm{O}_{3}$ and $\mathrm{NO}_{x}$ average mixing ratios. The enhancements of $\mathrm{O}_{3}$ by $\mathrm{NO}_{x}$ anthropogenic emissions from South and East Asia are closely linked to those of $\mathrm{CO}$ previously analyzed. As for $\mathrm{CO}$, sensitivity simulations with Indonesian anthropogenic and African $\mathrm{BB} \mathrm{NO}_{x}$ sources switched off (not shown) show very little impact on South Asian upper-tropospheric $\mathrm{O}_{3}$.

The $\mathrm{O}_{3}$ enhancements caused by East Asian emissions is the largest (>15 ppbv) below $300 \mathrm{hPa}$ between 90 and $120^{\circ}$ E. Convection is not strong enough over China to bring PBL $\mathrm{NO}_{x}$ deep into the AMA and, on average, uppertropospheric $\mathrm{O}_{3}$ enhancements from Chinese emissions are about 5 ppbv both within and outside of the AMA during July-August. Compared to Chinese emissions, South Asian emissions have a smaller impact on free-tropospheric $\mathrm{O}_{3}$ $\left(<12\right.$ ppbv) but a larger-scale impact on $\mathrm{O}_{3}$ in the upper troposphere and more specifically within the AMA. On average, South Asian emissions are responsible for an $\mathrm{O}_{3}$ (resp. $\mathrm{NO}_{x}$ ) increase of 8 (resp. 0.04) ppbv within the AMA and of about 5 (resp. 0.015) ppbv outside of the upper-level anticyclone (Table 3). Indian $\mathrm{NO}_{x}$ is uplifted and trapped within the AMA (see white contours in Fig. 14) and produces $\mathrm{O}_{3}$ molecules that are also trapped within the AMA. 
Jun.
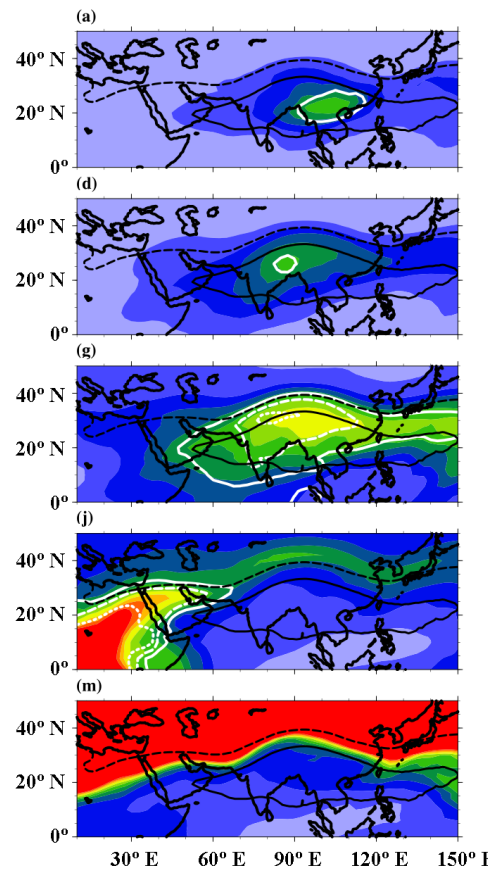

Jul

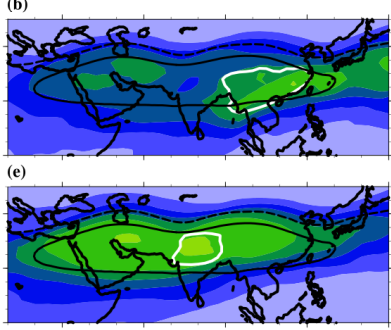

(h)

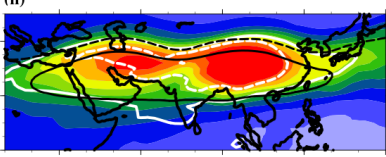

(k)

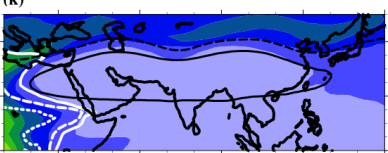

(n)

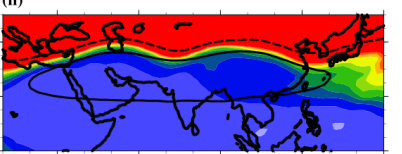

Sep.

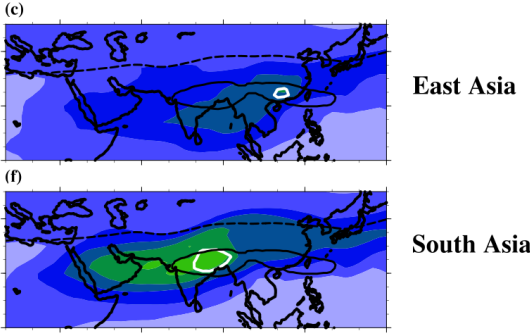

(i)

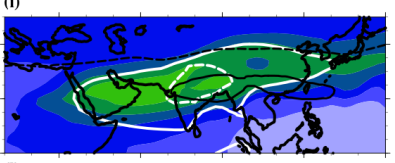

Asian LiNOx

(I)

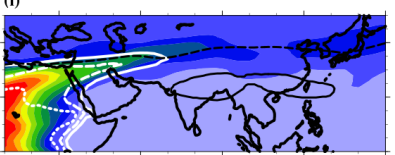

African LiNOx

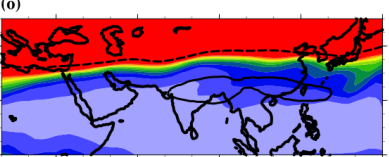

STE

Figure 14. Same as in Fig. 13 for the distributions at $200 \mathrm{hPa}$.

Asian $\mathrm{LiNO}_{x}$ is responsible for an important $\mathrm{O}_{3}$ production in the Asian upper troposphere mostly confined within the AMA (see Fig. 13h and i) with a strong intra-seasonal variability. In July, $\mathrm{LiNO}_{x}$ produces $13.5 \mathrm{ppbv} \mathrm{O}_{3}$ in the AMA and only 10 ppbv in August. In both cases, the $\mathrm{O}_{3}$ production outside of the AMA is half of its value within the AMA. For $\mathrm{NO}_{x}$, the production within the AMA is about 2.5 higher than outside of the AMA, highlighting the nonlinearity of the $\mathrm{O}_{3}$ production by $\mathrm{NO}_{x}$. The impact of African $\mathrm{LiNO}_{x}$ over Asia varies strongly from June to September. In June and September, when the AMA is weakened and located east of $90^{\circ} \mathrm{E}$, African $\mathrm{LiNO}_{x}$ has a large impact in the upper troposphere over the Middle East and in the free troposphere further east over India (Fig. 14). In July and August, the AMA circulation that extends to $30^{\circ} \mathrm{W}$ prevents air masses impacted by African $\mathrm{LiNO}_{x}$ from affecting $\mathrm{O}_{3}$ in the Middle East upper troposphere and the free troposphere over India is also less impacted than in June and September. During the July-August period, the large subsidence over the Middle East $\left(30-60^{\circ}\right.$ E) (see Fig. $9 b$ and c) brings $\mathrm{O}_{3}$ produced by both South Asian anthropogenic $\mathrm{NO}_{x}$ and Asian $\mathrm{LiNO}_{x}$ down to $400 \mathrm{hPa}$ (Fig. 13e and h) and contributes to the upper part of the mid-tropospheric $\mathrm{O}_{3}$ maximum. Below $400 \mathrm{hPa}$ and down to $600 \mathrm{hPa}$, the air masses coming from the west are not blocked by the AMA and both African $\mathrm{LiNO}_{x}$ and STE have a larger contribution to the free-tropospheric
Middle East $\mathrm{O}_{3}$ maximum (Fig. 13k and n) highlighted by GC and IASI (Fig. 7d and f) than Asian sources.

The last source of $\mathrm{O}_{3}$ in the Asian upper troposphere that we investigated are STE. At $200 \mathrm{hPa}$, STE are not an important contributor to the $\mathrm{O}_{3}$ distribution, as can be seen in Fig. 14. At this pressure level, stratospheric $\mathrm{O}_{3}$-rich air masses are kept outside of the AMA circulation. Nevertheless, on average, STE contribute from 7 to $12 \mathrm{ppbv} \mathrm{O}_{3}$ within the AMA (Table 3). These high values are caused by STE impacting the upper troposphere between $150 \mathrm{hPa}$ and the tropopause, as highlighted by the stratospheric $\mathrm{O}_{3}$ tracer cross sections in Fig. 13. It is also interesting to note that STE also impact the free troposphere over the Middle East and India in a very similar way to African $\mathrm{LiNO}_{x}$, traveling with the westerly winds below the AMA. The same eastward transport of Middle East $\mathrm{NO}_{x}$ emissions has been shown to slightly $(\sim 10 \%)$ impact $\mathrm{NO}_{x}$ and $\mathrm{O}_{3}$ distributions in the lower troposphere over India (Kunhikrishnan et al., 2006). Nevertheless, as discussed in Sect. 3, $\mathrm{O}_{3}$ from GC is overestimated in the lower and middle stratosphere $(24-90 \mathrm{hPa})$ by a factor of $\sim 1.7$. This overestimation most likely implies a similar overestimation in STE evaluated with the $\mathrm{O}_{3}$ stratospheric tracer and STE are probably responsible for a 4 to 7 ppbv $\mathrm{O}_{3}$ enhancement in the AMA.

Asian $\mathrm{LiNO}_{x}$ therefore appears to be the largest $\mathrm{NO}_{x}$ source within the AMA with a contribution to the $\mathrm{NO}_{x}$ con- 
centration that is 2 to 3 times larger than South Asian anthropogenic $\mathrm{NO}_{x}$ emissions. This result appears contradictory to that of Kunhikrishnan et al. (2004), who estimated that during the monsoon in the Indian upper troposphere 60 to $70 \%$ of $\mathrm{NO}_{x}$ come from local surface sources and only 20-25\% from $\mathrm{LiNO}_{x}$. This apparent contradiction is due to the fact that Kunhikrishnan et al. (2004) define the upper troposphere as the $500-150 \mathrm{hPa}$ while the AMA spans the $300-100 \mathrm{hPa}$ domain and, according to Fig. 13, $\mathrm{LiNO}_{x}$ has its largest impact between 200 and $100 \mathrm{hPa}$. Furthermore, the global annual $\mathrm{LiNO}_{x}$ source used in Kunhikrishnan et al. (2004) is $2.8 \mathrm{Tg}(\mathrm{N})$ year $^{-1}$, which is in the lower part of the $6 \pm 3 \operatorname{Tg}(\mathrm{N})$ year $^{-1}$ estimation from Schumann and Huntrieser (2007). In our GC simulations, the global annual $\mathrm{LiNO}_{x}$ source is set to $6 \mathrm{Tg}(\mathrm{N})$ year $^{-1}$. Concerning the impact of $\mathrm{NO}_{x}$ local sources on the upper-tropospheric (500-150 hPa) $\mathrm{O}_{3}$, Kunhikrishnan et al. (2004) found a maximum of $15 \%$. Similar results are found by Kunhikrishnan et al. (2006) with a 10 to $20 \%$ sensitivity of $\mathrm{O}_{3}$ to Indian $\mathrm{NO}_{x}$ emissions in the middle and upper troposphere (700$200 \mathrm{hPa}$ ) over India. From Fig. 14e and f, we can roughly estimate a production of $9 \mathrm{ppbv}$ in the $500-150 \mathrm{hPa}$ range and $60-95^{\circ} \mathrm{E}$ by Indian $\mathrm{NO}_{x}$ sources. For the same region, we also estimate a rough average of $60 \mathrm{ppbv} \mathrm{O}_{3}$ for the JulyAugust period from Fig. $7 \mathrm{~g}$ and $\mathrm{j}$. We have therefore an approximate $15 \%$ sensitivity of $\mathrm{O}_{3}$ to the Indian $\mathrm{NO}_{x}$ source in good agreement with Kunhikrishnan et al. (2004, 2006). According to Kunhikrishnan et al. (2006), $\mathrm{NO}_{x}$ emissions from Indonesia have a non-negligible effect on upper-tropospheric $\mathrm{NO}_{x}(20-30 \%)$ and $\mathrm{O}_{3}(10-15 \%)$ over India during the ASM period. They also state that the impact of Indonesian emissions is more important over the southern part of India through transport by the tropical easterly jet, which was especially strong in the 1997 El Niño year. This does not contradict the negligible impact of Indonesian emissions on the AMA composition that we have reported, the AMA being an isolated region north of the tropical easterly jet.

\section{Summary and conclusions}

In the present study, we have analyzed the $\mathrm{CO}$ and $\mathrm{O}_{3}$ distributions and budget in the upper-level AMA based on observations from the MetOp-A/IASI sensor and on simulations from the global chemistry transport model GC. Model simulations and spaceborne observations have shown a good general agreement for regional features and the seasonal variations of the upper-tropospheric distributions, with correlation coefficients of 0.70 for $\mathrm{CO}$ and 0.94 for $\mathrm{O}_{3}$. The higher correlation for $\mathrm{O}_{3}$ results from its high variability between the oceanic tropical upper troposphere and the extratropical lower stratosphere. Low CO bias in the lower-middle troposphere has been diagnosed in the simulations with both spaceborne IASI and MOZAIC in situ data. Such a bias was already identified by other studies with GC (Liu et al.,
2010, 2013). The convective uplift of CO is clearly detected by IASI in the monsoon region but the enhanced uppertropospheric $\mathrm{CO}$ resulting from westward transport in the AMA circulation is smoothed over the middle and upper troposphere. For $\mathrm{O}_{3}$, large biases resulting from an accentuation of the S-shape profiles by the AvK smoothing are found over the tropical oceanic regions.

Based on our IASI observations and model simulations, we have analyzed the $\mathrm{CO}$ and $\mathrm{O}_{3}$ distributions in relation to the AMA and monsoon convection. We first developed a method to characterize the 3-D boundaries of the AMA based on GH. We found that the AMA could be defined as the region with $\mathrm{GH}$ differences larger than $270 \mathrm{~m}$ relative to the $\mathrm{GH}$ averaged over the $50^{\circ} \mathrm{S}$ to $50^{\circ} \mathrm{N}$ band. Both observations and simulations have revealed an anti-correlation of $\mathrm{O}_{3}$ and $\mathrm{CO}$ in the middle and upper troposphere, with lower (higher) $\mathrm{O}_{3}(\mathrm{CO})$ in the eastern part of the domain corresponding to the ASM region than in the western part over the Middle East, northern Africa and the Eastern Mediterranean. This anti-correlation partly results from the convective uplift of freshly polluted air masses rich in $\mathrm{CO}$ but poor in $\mathrm{O}_{3}$ and of the subsidence of $\mathrm{O}_{3}$-enriched and $\mathrm{CO}$-poor air masses in the subsidence region in the western part of the domain.

In order to quantify the impact of the different emission sources on the Asian upper-tropospheric $\mathrm{CO}$ and $\mathrm{O}_{3}$ budget, we performed sensitivity simulations with $\mathrm{CO}$ and $\mathrm{NO}_{x}$ sources switched off by type and region and one simulation with tagged stratospheric $\mathrm{O}_{3}$. For $\mathrm{CO}$, it appears that South Asia is the most important contributor $(\sim 25 \mathrm{ppbv})$ to filling up the AMA because emissions (the IGP), convection and upper-level anticyclone coincide. East Asia is more polluted than South Asia but convection in this region is less strong than in South Asia and does not uplift pollution deep enough into the upper troposphere to contribute significantly to the AMA CO filling $(\sim 10 \mathrm{ppbv})$. For the same reason, $\mathrm{NO}_{x}$ from South Asian pollution sources contributes more to the $\mathrm{O}_{3}$ formation within the anticyclone $(\sim 8 \mathrm{ppbv})$ than $\mathrm{NO}_{x}$ from China $(\sim 5 \mathrm{ppbv})$. Nevertheless, $\mathrm{LiNO}_{x}$ from Asia is the most important contributor to the photochemical $\mathrm{O}_{3}$ formation within the AMA with a production which is up to 2 times larger (10-14 ppbv) than South Asian pollution. Finally, STE play an important role for $\mathrm{O}_{3}$ in the upper part of the AMA (above $150 \mathrm{hPa}$ ) with a contribution (7-10 ppbv) which is probably overestimated because of the stratospheric $\mathrm{O}_{3}$ overestimation by the model.

\section{Data availability}

The IASI-SOFRID $\mathrm{CO}$ and $\mathrm{O}_{3}$ research data used in this publication are publicly available at http://thredds.sedoo.fr/ iasi-sofrid-o3-co/. The MOZAIC-IAGOS data are available via http://www.iagos.fr/. IASI L1c and L2-EUMETSAT data have been downloaded from the Ether French atmospheric database (http://ether.ipsl.jussieu.fr). MERRA data used in 
this study were provided by the Global Modeling and Assimilation Office (GMAO) at NASA Goddard Space Flight Center through the NASA GES DISC online archive.

Acknowledgements. The research with IASI was conducted with financial support from the CNES (TOSCA-IASI project). MOZAIC is presently funded by INSU-CNRS, Météo-France, and FZJ (Forschungszentrum Julich, Germany).

Edited by: M. von Hobe

Reviewed by: two anonymous referees

\section{References}

Barret, B., Turquety, S., Hurtmans, D., Clerbaux, C., Hadji-Lazaro, J., Bey, I., Auvray, M., and Coheur, P.-F.: Global carbon monoxide vertical distributions from spaceborne high-resolution FTIR nadir measurements, Atmos. Chem. Phys., 5, 2901-2914, doi:10.5194/acp-5-2901-2005, 2005.

Barret, B., Ricaud, P., Mari, C., Attié, J.-L., Bousserez, N., Josse, B., Le Flochmoën, E., Livesey, N. J., Massart, S., Peuch, V.H., Piacentini, A., Sauvage, B., Thouret, V., and Cammas, J.P.: Transport pathways of $\mathrm{CO}$ in the African upper troposphere during the monsoon season: a study based upon the assimilation of spaceborne observations, Atmos. Chem. Phys., 8, 3231-3246, doi:10.5194/acp-8-3231-2008, 2008.

Barret, B., Williams, J. E., Bouarar, I., Yang, X., Josse, B., Law, K., Pham, M., Le Flochmoën, E., Liousse, C., Peuch, V. H., Carver, G. D., Pyle, J. A., Sauvage, B., van Velthoven, P., Schlager, H., Mari, C., and Cammas, J.-P.: Impact of West African Monsoon convective transport and lightning $\mathrm{NO}_{x}$ production upon the upper tropospheric composition: a multi-model study, Atmos. Chem. Phys., 10, 5719-5738, doi:10.5194/acp-10-57192010, 2010.

Barret, B., Le Flochmoen, E., Sauvage, B., Pavelin, E., Matricardi, M., and Cammas, J. P.: The detection of post-monsoon tropospheric ozone variability over south Asia using IASI data, Atmos. Chem. Phys., 11, 9533-9548, doi:10.5194/acp-11-95332011, 2011.

Bergman, J. W., Fierli, F., Jensen, E. J., Honomichl, S., and Pan, L. L.: Boundary layer sources for the Asian anticyclone: Regional contributions to a vertical conduit, J. Geophys. Res.Atmos., 118, 2560-2575, doi:10.1002/jgrd.50142, 2013.

Bey, I., Jacob, D. J., Logan, J. A., and Yantosca, R. M.: Asian chemical outflow to the Pacific in spring: Origins, pathways, and budgets, J. Geophys. Res.-Atmos., 106, 23097-23113, doi:10.1029/2001jd000806, 2001.

Chen, W.-T., Liao, H., and Seinfeld, J. H.: Future climate impacts of direct radiative forcing of anthropogenic aerosols, tropospheric ozone, and long-lived greenhouse gases, J. Geophys. Res.-Atmos., 112, D14209, doi:10.1029/2006jd008051, 2007.

Clerbaux, C., Boynard, A., Clarisse, L., George, M., Hadji-Lazaro, J., Herbin, H., Hurtmans, D., Pommier, M., Razavi, A., Turquety, S., Wespes, C., and Coheur, P.-F.: Monitoring of atmospheric composition using the thermal infrared IASI/MetOp sounder, Atmos. Chem. Phys., 9, 6041-6054, doi:10.5194/acp-9-6041-2009, 2009.
Cristofanelli, P., Bracci, A., Sprenger, M., Marinoni, A., Bonafè, U., Calzolari, F., Duchi, R., Laj, P., Pichon, J. M., Roccato, F., Venzac, H., Vuillermoz, E., and Bonasoni, P.: Tropospheric ozone variations at the Nepal Climate ObservatoryPyramid (Himalayas, $5079 \mathrm{~m}$ a.s.1.) and influence of deep stratospheric intrusion events, Atmos. Chem. Phys., 10, 6537-6549, doi:10.5194/acp-10-6537-2010, 2010.

De Wachter, E., Barret, B., Le Flochmoën, E., Pavelin, E., Matricardi, M., Clerbaux, C., Hadji-Lazaro, J., George, M., Hurtmans, D., Coheur, P.-F., Nedelec, P., and Cammas, J. P.: Retrieval of MetOp-A/IASI CO profiles and validation with MOZAIC data, Atmos. Meas. Tech., 5, 2843-2857, doi:10.5194/amt-5-28432012, 2012.

Doherty, R. M., Stevenson, D. S., Collins, W. J., and Sanderson, M. G.: Influence of convective transport on tropospheric ozone and its precursors in a chemistry-climate model, Atmos. Chem. Phys., 5, 3205-3218, doi:10.5194/acp-5-3205-2005, 2005.

Dufour, G., Eremenko, M., Griesfeller, A., Barret, B., LeFlochmoën, E., Clerbaux, C., Hadji-Lazaro, J., Coheur, P.-F., and Hurtmans, D.: Validation of three different scientific ozone products retrieved from IASI spectra using ozonesondes, Atmos. Meas. Tech., 5, 611-630, doi:10.5194/amt-5-611-2012, 2012.

Eastham, S. D., Weisenstein, D. K., and Barrett, S. R. H.: Development and evaluation of the unified troposphericstratospheric chemistry extension (UCX) for the global chemistry-transport model GEOS-Chem, Atmos. Environ., 89, 52-63, doi:10.1016/j.atmosenv.2014.02.001, 2014.

Eremenko, M., Dufour, G., Foret, G., Keim, C., Orphal, J., Beekmann, M., Bergametti, G., and Flaud, J. M.: Tropospheric ozone distributions over Europe during the heat wave in July 2007 observed from infrared nadir spectra recorded by IASI, Geophys. Res. Lett., 35, L18805, doi:10.1029/2008g1034803, 2008.

Fiore, A., Jacob, D., Bey, I., Yantosca, R., Field, B., Fusco, A., and Wilkinson, J.: Background ozone over the United States in summer: Origin, trend, and contribution to pollution episodes, J. Geophys. Res.-Atmos., 107, ACH11-1-ACH11-25, doi:10.1029/2001JD000982, 2002.

Garny, H. and Randel, W.: Dynamic variability of the Asian monsoon anticyclone observed in potential vorticity and correlations with tracer distributions, J. Geophys. Res.-Atmos., 118, 1342113433, doi:10.1002/2013JD020908, 2013.

George, M., Clerbaux, C., Hurtmans, D., Turquety, S., Coheur, P.F., Pommier, M., Hadji-Lazaro, J., Edwards, D. P., Worden, H., Luo, M., Rinsland, C., and McMillan, W.: Carbon monoxide distributions from the IASI/METOP mission: evaluation with other space-borne remote sensors, Atmos. Chem. Phys., 9, 8317-8330, doi:10.5194/acp-9-8317-2009, 2009.

Heath, N. K. and Fuelberg, H. E.: Using a WRF simulation to examine regions where convection impacts the Asian summer monsoon anticyclone, Atmos. Chem. Phys., 14, 2055-2070, doi:10.5194/acp-14-2055-2014, 2014.

Hoskins, B. J. and Rodwell, M. J.: A Model of the Asian Summer Monsoon. Part I: The Global Scale, J. Atmos. Sci., 52, 13291340, 1995.

Jacob, D. J., Heikes, B. G., Fan, S. M., Logan, J. A., Mauzerall, D. L., Bradshaw, J. D., Singh, H. B., Gregory, G. L., Talbot, R. W., Blake, D. R., and Sachse, G. W.: Origin of ozone and $\mathrm{NO}_{x}$ in the tropical troposphere: A photochemical analysis of 
aircraft observations over the South Atlantic basin, J. Geophys. Res.-Atmos., 101, 24235-24250, doi:10.1029/96jd00336, 1996.

Kar, J., Bremer, H., Drummond, J. R., Rochon, Y. J., Jones, D. B. A., Nichitiu, F., Zou, J., Liu, J., Gille, J. C., Edwards, D. P., Deeter, M. N., Francis, G., Ziskin, D., and Warner, J.: Evidence of vertical transport of carbon monoxide from Measurements of Pollution in the Troposphere (MOPITT), Geophys. Res. Lett., 31, L23105, doi:10.1029/2004g1021128, 2004.

Kunhikrishnan, T., Lawrence, M. G., von Kuhlmann, R., Richter, A., Ladstatter-Weissenmayer, A., and Burrows, J. P.: Analysis of tropospheric $\mathrm{NO}_{x}$ over Asia using the model of atmospheric transport and chemistry (MATCH-MPIC) and GOME-satellite observations, Atmos. Environ., 38, 581-596, doi:10.1016/j.atmosenv.2003.09.074, 2004.

Kunhikrishnan, T., Lawrence, M. G., von Kuhlmann, R., Wenig, M. O., Asman, W. A. H., Richter, A., and Burrows, J. P.: Regional $\mathrm{NO}_{x}$ emission strength for the Indian subcontinent and the impact of emissions from India and neighboring countries on regional O-3 chemistry, J. Geophys. Res.-Atmos., 111, D15301, doi:10.1029/2005jd006036, 2006.

Lawrence, M. G., von Kuhlmann, R., Salzmann, M., and Rasch, P. J.: The balance of effects of deep convective mixing on tropospheric ozone, Geophys. Res. Lett., 30, 1940, doi:10.1029/2003g1017644, 2003.

Li, Q. B., Jacob, D. J., Logan, J. A., Bey, I., Yantosca, R. M., Liu, H. Y., Martin, R. V., Fiore, A. M., Field, B. D., Duncan, B. N., and Thouret, V.: A tropospheric ozone maximum over the Middle East, Geophys. Res. Lett., 28, 3235-3238, doi:10.1029/2001g1013134, 2001.

Li, Q. B., Jiang, J. H., Wu, D. L., Read, W. G., Livesey, N. J., Waters, J. W., Zhang, Y. S., Wang, B., Filipiak, M. J., Davis, C. P., Turquety, S., Wu, S. L., Park, R. J., Yantosca, R. M., and Jacob, D. J.: Convective outflow of South Asian pollution: A global CTM simulation compared with EOS MLS observations, Geophys. Res. Lett., 32, L14826, doi:10.1029/2005g1022762, 2005.

Liousse, C., Guillaume, B., Grégoire, J. M., Mallet, M., Galy, C., Pont, V., Akpo, A., Bedou, M., Castéra, P., Dungall, L., Gardrat, E., Granier, C., Konaré, A., Malavelle, F., Mariscal, A., Mieville, A., Rosset, R., Serça, D., Solmon, F., Tummon, F., Assamoi, E., Yoboué, V., and Van Velthoven, P.: Updated African biomass burning emission inventories in the framework of the AMMAIDAF program, with an evaluation of combustion aerosols, Atmos. Chem. Phys., 10, 9631-9646, doi:10.5194/acp-10-96312010, 2010.

Liu, J., Logan, J. A., Jones, D. B. A., Livesey, N. J., Megretskaia, I., Carouge, C., and Nedelec, P.: Analysis of CO in the tropical troposphere using Aura satellite data and the GEOS-Chem model: insights into transport characteristics of the GEOS meteorological products, Atmos. Chem. Phys., 10, 12207-12232, doi:10.5194/acp-10-12207-2010, 2010.

Liu, J., Logan, J. A., Murray, L. T., Pumphrey, H. C., Schwartz, M. J., and Megretskaia, I. A.: Transport analysis and source attribution of seasonal and interannual variability of $\mathrm{CO}$ in the tropical upper troposphere and lower stratosphere, Atmos. Chem. Phys., 13, 129-146, doi:10.5194/acp-13-129-2013, 2013.

Liu, J. J., Jones, D. B. A., Worden, J. R., Noone, D., Parrington, M., and Kar, J.: Analysis of the summertime buildup of tropospheric ozone abundances over the Middle East and North Africa as observed by the Tropospheric Emission Spec- trometer instrument, J. Geophys. Res.-Atmos., 114, D05304, doi:10.1029/2008jd010993, 2009.

Marenco, A., Thouret, V., Nedelec, P., Smit, H., Helten, M., Kley, D., Karcher, F., Simon, P., Law, K., Pyle, J., Poschmann, G., Von Wrede, R., Hume, C., and Cook, T.: Measurement of ozone and water vapor by Airbus in-service aircraft: The MOZAIC airborne program, An overview, J. Geophys. Res.-Atmos., 103, 25631-25642, doi:10.1029/98jd00977, 1998.

Martin, R. V., Jacob, D., Logan, J., Bey, I., Yantosca, R., Staudt, A., Li, Q., Fiore, A., Duncan, B., Liu, H., Ginoux, P., and Thouret, V.: Interpretation of TOMS observations of tropical tropospheric ozone with a global model and in-situ observations, J. Geophys. Res.-Atmos., 107, ACH 4-1-ACH 4-27, doi:10.1029/2001JD001480, 2002.

Martin, R. V., Sauvage, B., Folkins, I., Sioris, C. E., Boone, C., Bernath, P., and Ziemke, J.: Space-based constraints on the production of nitric oxide by lightning, J. Geophys. Res.-Atmos., 112, D09309, doi:10.1029/2006jd007831, 2007.

McLinden, C. A., Olsen, S. C., Hannegan, B., Wild, O., Prather, M. J., and Sundet, J.: Stratospheric ozone in 3-D models: A simple chemistry and the cross-tropopause flux, J. Geophys. Res.Atmos., 105, 14653-14665, doi:10.1029/2000jd900124, 2000.

Moorthi, S. and Suarez, M. J.: Relaxed Arakawa-Schubert - A parameterization of moist convection for general-circulation models, Mon. Weather Rev., 120, 978-1002, doi:10.1175/15200493(1992)120<0978:rasapo>2.0.co;2, 1992.

Murray, L., Jacob, D., Logan, J., Hudman, R., and Koshah, W.: Optimized regional and interannual variability of lightning in a global chemical transport model constrained by LIS/OTD satellite data, J. Geophys. Res.-Atmos., 117, D20307, doi:10.1029/2012JD017934, 2012.

Nassar, R., Logan, J. A., Megretskaia, I. A., Murray, L. T., Zhang, L., and Jones, D. B. A.: Analysis of tropical tropospheric ozone, carbon monoxide, and water vapor during the 2006 El Nino using TES observations and the GEOS-Chem model, J. Geophys. Res.Atmos., 114, D17304, doi:10.1029/2009jd011760, 2009.

Nedelec, P., Cammas, J.-P., Thouret, V., Athier, G., Cousin, J.-M., Legrand, C., Abonnel, C., Lecoeur, F., Cayez, G., and Marizy, C.: An improved infrared carbon monoxide analyser for routine measurements aboard commercial Airbus aircraft: technical validation and first scientific results of the MOZAIC III programme, Atmos. Chem. Phys., 3, 1551-1564, doi:10.5194/acp-3-15512003, 2003.

Park, M., Randel, W. J., Gettelman, A., Massie, S. T., and Jiang, J. H.: Transport above the Asian summer monsoon anticyclone inferred from Aura Microwave Limb Sounder tracers, J. Geophys. Res.-Atmos., 112, D16309, doi:10.1029/2006jd008294, 2007.

Park, M., Randel, W. J., Emmons, L. K., Bernath, P. F., Walker, K. A., and Boone, C. D.: Chemical isolation in the Asian monsoon anticyclone observed in Atmospheric Chemistry Experiment (ACE-FTS) data, Atmos. Chem. Phys., 8, 757-764, doi:10.5194/acp-8-757-2008, 2008.

Park, M., Randel, W. J., Emmons, L. K., and Livesey, N. J.: Transport pathways of carbon monoxide in the Asian summer monsoon diagnosed from Model of Ozone and Related Tracers (MOZART), J. Geophys. Res.-Atmos., 114, D08303, doi:10.1029/2008jd010621, 2009. 
Ploeger, F., Gottschling, C., Griessbach, S., Grooß, J.-U., Guenther, G., Konopka, P., Müller, R., Riese, M., Stroh, F., Tao, M., Ungermann, J., Vogel, B., and von Hobe, M.: A potential vorticitybased determination of the transport barrier in the Asian summer monsoon anticyclone, Atmos. Chem. Phys., 15, 13145-13159, doi:10.5194/acp-15-13145-2015, 2015.

Popovic, J. M. and Plumb, R. A.: Eddy shedding from the uppertropospheric Asian monsoon anticyclone, J. Atmos. Sci., 58, 93 104, doi:10.1175/1520-0469(2001)058<0093:esftut>2.0.co;2, 2001.

Price, C. and Rind, D.: Modeling global lightning distributions in a general circulation model, Mon. Weather Rev., 122, 1930-1939, doi:10.1175/1520-0493(1994)122<1930:MGLDIA>2.0.CO;2, 1994.

Randel, W. J. and Park, M.: Deep convective influence on the Asian summer monsoon anticyclone and associated tracer variability observed with Atmospheric Infrared Sounder (AIRS), J. Geophys. Res.-Atmos., 111, D12314, doi:10.1029/2005jd006490, 2006.

Randel, W. J., Park, M., Emmons, L., Kinnison, D., Bernath, P., Walker, K. A., Boone, C., and Pumphrey, H.: Asian Monsoon Transport of Pollution to the Stratosphere, Science, 328, 611613, doi:10.1126/science.1182274, 2010.

Rodgers, C. D.: Inverse methods for atmospheric sounding: Theory and Practice, Series on Atmospheric, Oceanic and Planetary Physics - Vol. 2, World Scientific, Singapore, New Jersey, London, Hong Kong, 238 pp., 2000.

Sauvage, B., Thouret, V., Cammas, J.-P., Gheusi, F., Athier, G., and Nédélec, P.: Tropospheric ozone over Equatorial Africa: regional aspects from the MOZAIC data, Atmos. Chem. Phys., 5, 311335, doi:10.5194/acp-5-311-2005, 2005.

Sauvage, B., Martin, R. V., van Donkelaar, A., Liu, X., Chance, K., Jaeglé, L., Palmer, P. I., Wu, S., and Fu, T.-M.: Remote sensed and in situ constraints on processes affecting tropical tropospheric ozone, Atmos. Chem. Phys., 7, 815-838, doi:10.5194/acp-7-815-2007, 2007a.

Sauvage, B., Martin, R. V., van Donkelaar, A., and Ziemke, J. R.: Quantification of the factors controlling tropical tropospheric ozone and the South Atlantic maximum, J. Geophys. Res.Atmos., 112, D11309, doi:10.1029/2006jd008008, 2007b.

Schumann, U. and Huntrieser, H.: The global lightning-induced nitrogen oxides source, Atmos. Chem. Phys., 7, 3823-3907, doi:10.5194/acp-7-3823-2007, 2007.

Shindell, D. T., Faluvegi, G., Stevenson, D. S., Krol, M. C., Emmons, L. K., Lamarque, J. F., Petron, G., Dentener, F. J., Ellingsen, K., Schultz, M. G., Wild, O., Amann, M., Atherton, C. S., Bergmann, D. J., Bey, I., Butler, T., Cofala, J., Collins, W. J., Derwent, R. G., Doherty, R. M., Drevet, J., Eskes, H. J., Fiore, A. M., Gauss, M., Hauglustaine, D. A., Horowitz, L. W., Isaksen, I. S. A., Lawrence, M. G., Montanaro, V., Mueller, J. F., Pitari, G., Prather, M. J., Pyle, J. A., Rast, S., Rodriguez, J. M., Sanderson, M. G., Savage, N. H., Strahan, S. E., Sudo, K., Szopa, S., Unger, N., van Noije, T. P. C., and Zeng, G.: Multimodel simulations of carbon monoxide: Comparison with observations and projected near-future changes, J. Geophys. Res.-Atmos., 111, D19306, doi:10.1029/2006jd007100, 2006.
Streets, D. G., Yu, C., Bergin, M. H., Wang, X. M., and Carmichael, G. R.: Modeling study of air pollution due to the manufacture of export goods in China's Pearl River Delta, Environ. Sci. Technol., 40, 2099-2107, doi:10.1021/es051275n, 2006.

Thouret, V., Marenco, A., Logan, J. A., Nedelec, P., and Grouhel, C.: Comparisons of ozone measurements from the MOZAIC airborne program and the ozone sounding network at eight locations, J. Geophys. Res.-Atmos., 103, 25695-25720, doi:10.1029/98jd02243, 1998.

Tocquer, F., Barret, B., Mari, C., Le Flochmoen, E., Cammas, J.P., and Sauvage, B.: An upper tropospheric "ozone river" from Africa to India during the 2008 Asian post-monsoon season, Tellus B, 67, 25350, doi:10.3402/tellusb.v67.25350, 2015.

van der Werf, G. R., Randerson, J. T., Giglio, L., Collatz, G. J., Mu, M., Kasibhatla, P. S., Morton, D. C., DeFries, R. S., Jin, Y., and van Leeuwen, T. T.: Global fire emissions and the contribution of deforestation, savanna, forest, agricultural, and peat fires (19972009), Atmos. Chem. Phys., 10, 11707-11735, doi:10.5194/acp10-11707-2010, 2010.

Vogel, B., Günther, G., Müller, R., Grooß, J.-U., and Riese, M.: Impact of different Asian source regions on the composition of the Asian monsoon anticyclone and of the extratropical lowermost stratosphere, Atmos. Chem. Phys., 15, 13699-13716, doi:10.5194/acp-15-13699-2015, 2015.

Wu, S., Mickley, L., Jacob, D., Logan, J., Yantosca, R., and Rind, D.: Why are there large differences between models in global budgets of tropospheric ozone?, J. Geophys. Atmos., 112, D05302, doi:10.1029/2006JD007801, 2007.

Yamasoe, M. A., Sauvage, B., Thouret, V., Nédélec, P., Le Flochmoen, E., and Barret, B.: Analysis of tropospheric ozone and carbon monoxide profiles over South America based on MOZAIC/IAGOS database and model simulations, Tellus B, 67, 27884, doi:10.3402/tellusb.v67.27884, 2015.

Yan, R. and Bian, J.: Tracing the boundary layer sources of carbon monoxide in the Asian summer monsoon anticyclone using WRF-Chem, Adv. Atmos. Sci., 32, 943-951, doi:10.1007/s00376-014-4130-3, 2015.

Zhang, Q., Wu, G., and Qian, Y.: Asia high and its relationship to the climate anomaly over East Asia in summer, J. Meteorol. Soc. Jpn., 80, 733-744, 2002. 